\title{
CAN THE UNSOPHISTICATED MARKET PROVIDE DISCIPLINE?
}

\section{Gerard Caprio and Patrick Honohan}

\author{
The World Bank
}

\begin{abstract}
World Bank Policy Research Working Paper 3364, August 2004
The Policy Research Working Paper Series disseminates the findings of work in progress to encourage the exchange of ideas about development issues. An objective of the series is to get the findings out quickly, even if the presentations are less than fully polished. The papers carry the names of the authors and should be cited accordingly. The findings, interpretations, and conclusions expressed in this paper are entirely those of the authors. They do not necessarily represent the view of the World Bank, its Executive Directors, or the countries they represent. Policy Research Working Papers are available online at http://econ.worldbank.org.
\end{abstract}

Paper prepared for the BIS-Chicago Fed Conference on Market Discipline. This paper draws on data from a wider effort to assess bank regulatory issues; the cooperation of Jim Barth, Maria Carkovic, Cindy Lee, Ross Levine, Ying Lin and Guillermo Noguera are acknowledged. 


\section{Introduction}

Despite significant upgrading of bank regulations and supervisory capacity and expertise, there has been little evident improvement in bank failure experience worldwide over the past decade. In addition, cross-country evidence suggests that systems that are overregulated by discretionary official supervisors - ostensibly in the interests of prudence underperform along a number of dimensions. Perhaps most interestingly, an approach based on strengthening official supervision was found at best to have no significant effect on the development of the financial sector; at worst, except in the most institutionally advanced countries, the effect went the other way (increased supervisory powers associated with less financial sector development). Instead, evidence from a crosscountry survey suggests that banking systems work better where market discipline is fostered by strict accounting and auditing rules, use of international rating agencies by banks, and avoidance of deposit insurance (Barth, Caprio and Levine, 2003).

But how much reliance can one place on market forces where the liquidity, transparency and other underlying characteristics of markets are deficient? Specifically, which elements of market discipline work better in immature environments? Most practitioners think that, as markets plainly do not function well in low-income countries, then it must be the case that market discipline also does not work, and that therefore these countries need to rely more heavily on capital and bank supervision, the two pillars stressed in the approach of the Basel Committee. Is this presumption correct?

This paper reviews the different channels of market discipline, discussing how they work, what the policy and institutional prerequisites are, and outlining existing empirical evidence. New data on the changing degree to which these pre-requisites are in place are presented. Using this data and proxies for the degree of banking vulnerability, we will provide some evidence on the presence of prerequisites for the different flavors in different countries and on their possible effectiveness. However market discipline does function, empirical evidence indicates that it does a better job compared with reliance unofficial supervision. While attempts to improve the latter no doubt should and will continue, there is much to be said in favor of building on strengths. Accordingly, the last section of the paper addresses policy considerations regarding what can be done to improve the functioning of market discipline.

To summarize our findings, there is no systematic tendency for low-income countries to lack the pre-requisites for market discipline. Offsetting factors to the weaker market and formal information infrastructures are (i) the less complex character of banking business in low-income countries; (ii) the growing internationalization of these markets through the presence of foreign banks, and through international trading of the debt and equity of locally-controlled non-government banks; and (iii) the smaller size of the business and financial community. On the other hand, continuing dominance by public sector banks in some countries limits the likely development of market monitoring, clearly a cause for concern, given the disappointing record of governments around the world as monitors of their self-owned banks. 
Among the different channels of market discipline, low-income countries are best positioned to exploit depositor discipline if the government avoids the chilling effects of blanket guarantees and the like. Because depositor discipline is effectively in the hands of a small number of large depositors, the information requirements for depositor discipline may be more easily satisfied in an economy where the financial and business elite is small, as it is in many of the lower-income countries.

Though local institutional deficiencies can appear to be a limiting factor, the effectiveness of discipline through debt and equity markets in low income countries is enhanced by the increasing tendency for privately controlled banks in developing countries to make their equity available for depository receipt (DR) trading on international markets, and to issue internationally traded debt. The use of information intermediaries (accounting firms and rating agencies) is also growing rapidly in low income countries, but their independent ability to contribute to market discipline seems rather limited given the heightened conflicts of interest in small business communities and the modest resources that are typically devoted to ratings.

Although market monitoring appears to be better developed in low-income countries, relative perhaps to expectations, it still is the case that more can and should be done to strengthen it. Although we find some evidence that countries where there is greater scope for local monitoring (because their banking systems are not predominantly governmentowned or foreign-owned) do employ policies friendly to market discipline, it is of some concern that there has been some drop overall in the use of such policies overall. Importantly, we do not suggest that current or prospective levels of market monitoring would be sufficient to protect small developing countries from banking crises, as these results in part from the greater nominal, real, and financial volatility that these economies suffer (World Bank, 2001). However, we do think that strengthening market monitoring will help both in limiting the cost of crises and in reducing the likelihood of crises that originate from within the banking sector.

\section{Market Monitors: The Players and the Issues}

Depositors, debt holders, outside equity holders, and information specialists (e.g. rating agencies and independent auditors) all have a potential role to play, but to differing degrees in different countries, depending for example on the level of financial development and on the international openness. ${ }^{1}$ While there is a considerable overlap between the mechanisms involved, each of these classes of agent exercises discipline in contrasting ways. It is the distinctive characteristic of depositors that they will withdraw their funds in response to a shift in risk, whereas it is the prices of traded bonds that will

\footnotetext{
${ }^{1}$ Another dimension sometimes mentioned as part of market discipline is reliance on banks' internal risk evaluations rather than on the views of supervisors, or simple mechanical rules linking provisioning and capital requirements with objective characteristics of the loan portfolio and other dimensions of the banks. Here it is the internal evaluations of the bank - admittedly a market entity - that are being employed rather than the rest of the market external to each bank. It seems to stretch the definition a bit wide to include this dimension. Even if they are they part of the market discipline story, they are still largely irrelevant for almost all developing countries.
} 
fall if a bank becomes distressed. Equity holders are sensitive to the potential for upside as well as downside. Large depositors, bondholders and outside equity holders, while they may be few, are potentially many. In contrast, approved rating agencies, and to a lesser extent auditing firms, are typically a small and relatively closed group.

For economies with advanced financial systems the argument for market discipline is especially one driven by the increased complexity of finance. In these economies (according to research findings) neither regulators nor the market have the monopoly of wisdom. ${ }^{2}$ Market forces can help improve discipline in the banking system by helping to monitor the conduct and condition of the banks (Flannery, 2001). The complexity argument is also relevant for developing countries: even if their financial systems are simpler, nevertheless supervisory capacity is also more limited and the relative effectiveness of risk-assessment by supervisors may be weaker. If so, having market participants help in the monitoring function is even more important.

But market discipline goes beyond monitoring and turns it into discipline by bringing influence to bear directly or indirectly on bank behavior. The direct influence come by altering the incentives for bank insiders, especially by increasing the cost of their funding. Even in the US, however, the indications are that such direct incentive effects are not sufficient to fully correct for excessive risk-taking (Bliss and Flannery, 2001). The indirect mechanism comes by the way in which market behavior serves to signal the results of monitoring to official regulators through its effect on asset prices or flows. The supervisors can then take supplementary action to influence bank behavior, for example through direct action to restrain bank behavior, or by an increase in risk-dependent deposit insurance premia, for example.

Note that the indirect signaling mechanism needs to be complemented by effective official intervention, whereas the direct incentive mechanism is more self-policing. More subtly, market participants who are placed at risk can, through political or macroeconomic mechanisms, also influence the policy environment, including the rigor with which regulations are enforced. The more transparent and conspicuous the market signal, the less scope the supervisor will have for covert forbearance.

Both the monitoring and influence ability of both the market and the official supervisor may depend on national institutional characteristics, but it is unclear how rapid these abilities decline as we go down the institutional quality scale and which declines relatively more.

\footnotetext{
${ }^{2}$ Interestingly, US studies which employ information on the timing of bank examiner downgrades show that equity prices have tended to fall (Berger, Davies \& Flannery, 2000) following examiner downgrades but spreads on subordinated debt narrow some quarters after downgrades (De Young, Flannery, Lang and Sorescu, 2001). The findings can be reconciled by assuming that shortly after the downgrade, the market discovers not only that (i) losses have been incurred (bad for equities) but (ii) corrective action is being taken (good for bond holders).
} 


\section{A. The role of large depositors}

\section{The mechanism}

The simplicity of the mechanism of depositor discipline is deceptive. Large depositors may inform themselves about the condition of a bank, but will also be highly sensitive to any increase in risk because of the nature of the deposit contract. There can be no upside gain on an existing deposit, so withdrawal is the optimal strategy in case of an increase in the perceived risk. (This is in contrast to a bond, which an existing holder must sell on the market, thereby incurring a capital loss: the bond's price falls to the point where demand is sufficient to clear the market). This feature of the deposit contract both keeps banks on their toes (Calomiris and Kahn), and creates the risk of a contagious bank run (Diamond and Dybvig). Indeed the perceived risk of instability associated with the contagious run has often been invoked to justify safety net intervention, which would serve to reduce the risk sensitivity of depositors.

In addition to the threat of withdrawals in response to an increase in risk, which is the distinctive characteristic of the depositor discipline, there is the additional effect in equilibrium that banks will have to offer the marginal depositor a sufficient rate of return to compensate for risk (in addition to convenience factors and other characteristics of the deposit variations in which may often be much more important than default risk) (cf. Hannan and Hanweck, 1988). If all depositors share the same information, one can imagine a pure price effect, with no change in the volume of deposits. On the other hand, as noted by Park and Peristiani, if there are differences of opinion among depositors as to the risk being taken, a change in risk could lead to a new equilibrium with lower deposits and a higher interest rate.

\section{Political economy}

Removing or downgrading the safety net, thereby allowing this mechanism to function, is usually politically problematic. Even if there is a ceiling to formal deposit insurance, the blanket extension in practice of deposit insurance whenever there is a systemic crisis, and the active use of a lender of last resort facility, both serve to insulate, albeit partially, the depositors from the consequences of risky behavior. This insulation is likely to be higher where governments have some degree of credibility. It is at the lowest levels of government credibility that the depositors may feel themselves exposed to bank risk.

\section{Market pre-requisites}

Unlike the situation with the other three agencies of market discipline, bank depositors are present in all countries. Accordingly, at a certain level, aside from the usual concerns about possible free-riding, the market pre-requisites for this mechanism are always present. It is the availability and perceived likelihood of bail-outs that undermines the effectiveness of these markets. A key factor in assessing the likely effectiveness of depositor monitoring is the nature of the information environment. In most developing countries, economic power and wealth are concentrated within a relatively small business elite and it seems reasonable to draw parallels with other small business communities such as those in which depositor discipline is thought to have worked well, such as the 
extensively documented cases of $18^{\text {th }}$ Century Scotland and early $19^{\text {th }}$ Century New England (Kroszner, 1997; Lamoreaux, 1994).

\section{Evidence}

There is a growing body of evidence (since Baer and Brewer, 1986) on the negative correlation between various indicators of bank quality and interest rate paid for deposits and a positive correlation with deposit growth.

The major route for depositor discipline is through withdrawal. Probably the biggest episode of deposit withdrawals in recent times was the loss of one-fifth of the deposit base in the Tequila crisis of 1994-5 in Argentina. Calomiris and Powell (2001) cite evidence that it was the banks that were objectively weaker and those which subsequently proved to be insolvent that were the subject of the most severe withdrawals, suggesting that this form of depositor discipline can be a discriminating one, and is not necessarily caught up in a contagious race for all exits, even in such a systemically grave crisis (see also D'Amato, Grubisic, and Powell, 1997).

Withdrawal can also be permanent. If informed large depositors remain persistently dubious about the quality of bank governance, then they will stay away - even placing their funds outside the country. ${ }^{3}$

Depositors do seem to demand higher returns from risky banks. Although many of the earlier US studies found little relation between measures of bank risk and interest rates, suggesting that there was perhaps more of an expectation of regulatory bailout in earlier times, the relationship is more recently clearly evident in the data (cf. park and Peristiani). For developing countries too there is a growing body of evidence that bank risk is evident in interest rates: Barajas and Steiner (2000) provide evidence for Colombia; Davies and Robitaille (1997) for Chile; Martinez Peria and Schmukler (2001) for Argentina, Chile and Mexico; Mondschean and Opiela (1999) for Poland; Opiela (2001) for Thailand. Moreover, the extensive cross country study of Demirgüç-Kunt and Huizinga (2004) showed that in the absence of explicit deposit insurance, banks growing their portfolios rapidly had to pay an increasing cost for their funding.

The discovery by Martinez Peria and Schmukler that banks with a higher share of nonperforming loans (seen as a measure of risk) seem to lose share in the deposit market and to pay an interest rate premium even in the presence of deposit insurance, has been interpreted as implying that deposit insurance is more credible in some countries than in others (Chile more credible than Argentina ${ }^{4}$ ). But it also alerts us to the need to hunt for alternative and supplementary reasons (other than risk) for differences between the interest rates paid by different banks.

\footnotetext{
${ }^{3}$ The low money-to-GDP ratios (even conditional on inflation) in Sub-Saharan Africa, a low income region which has experienced above average incidence of depositor losses in banking crises, can be taken as indirect evidence of this.

${ }^{4}$ They find that a bank's ratio of insured to uninsured depositors is risk-sensitive in Chile, but not in Argentina, suggesting that the Argentine deposit insurance system lacked credibility.
} 
Note, however, that several of these studies use average interest cost of funds in lieu of marginal interest rates paid. To the extent that banks with a large retail branch network, or those with heavy reliance on checking deposits, likely source their funds at lower average interest costs, though paying the same wholesale marginal interest rates as the rest of the market, this could introduce systematic bias. Wholesale banks will, for example, tend to have a lower percentage of their deposits covered by insurance and also be paying a higher average interest cost of funds, but these two facts will be wholly unrelated. There has to be some doubt as to whether, in such circumstances, the research is cleanly extracting bank confidence effects. ${ }^{5}$

Is the direct influence effect of informed depositor behavior sufficient to ensure efficient risk decisions by the bankers? Even in advanced economies, the cost penalty imposed on risky banks by sophisticated depositors is small - too small, it seems, to accomplish a sizable alteration in the risk-preference of the bank insiders (Park and Peristiani).

This does not take account of the depositor run mechanism with which we began this section. No quantitative empirical evidence has been adduced on this mechanism, despite the fact that it is likely to be a much more effective direct form of discipline than the small interest differentials observed.

To the extent that the behavior of depositors results in only a small interest differential, the most important aspect of depositors influence must be on the policy environment and this can be relevant even in countries with weak governance structures. In open economies where sophisticated depositors perceive too much risk-taking, they may already have moved most of their funds abroad, thereby lowering the marginal response of deposit rates or flows to changes in bank risk.

\section{B. Subordinated debt}

\section{The mechanism}

In addition to insisting on a minimum buffer of capital adequacy, it has been suggested (Calomiris, 1999a,b, see Board of Governors of the Federal Reserve System, 1999) that banks should be required to issue a certain amount - for example a given fraction of total assets - of subordinated debt. The bank's inability to do this, or the level of the yield it is required to pay, will signal its riskiness to the regulator as well as increasing the cost of a risky bank's operations.

This ingenious suggestion that subordinated debt should be used as a market-discipline device is one that has been widely misunderstood. Indeed, inasmuch as the voluntary issuance of sub debt is often seen by bank insiders as a cheap and stable source of

\footnotetext{
${ }^{5}$ Some authors doubt whether risky banks could logically face higher interest rates in a market where a credible deposit insurance scheme is present. Thus, Billet et al (1998) for the US argued that banks could substitute insured deposits for uninsured if the latter started to cost more because of risk effects. But Morgan and Stiroh argue that banks face an upward-sloping supply of insured deposits because of limited capacity of the local area - likely relevant for developing countries also - and in that case (except for a corner solution) the risky-yield on bonds is still the marginal cost of funds.
} 
funding and of meeting capital requirements, it might seem implausible that sub debt could be at the heart of a market discipline system. In fact, however, the proposal, in its most promising forms, is a more subtle and complex one than is often represented, and involves certain restrictions that greatly enhance the disciplining function. For one thing, to satisfy the requirements of the scheme, qualifying sub debt must be held by independent institutional investors and not either by insiders or by the retail public. This restriction on holders is intended to ensure that the holders have the capacity and motivation to inform themselves about the condition of the bank in that their investments will effectively be like a "canary in the coal-mine," losing their value before the deposit insurer incurs a loss. The second important restriction (not imposed in the Argentine case) is that the yield on qualifying bonds must not exceed a certain level (measured against current money-market yields). This ensures that the sub-debt does not simply become a junk bond yielding a sufficiently high coupon to compensate for even a high risk of default, thereby weakening the investors' incentive to assess that risk carefully. By imposing this interest ceiling, albeit on a limited class of liabilities, the scheme effectively rules out the kinds of high-interest high-risk equilibria discussed by HellmanMurdock-Stiglitz (2000).

\section{Political economy}

The political economy of the sub debt requirement is also somewhat promising. Losses incurred by institutional investors from the holding of a bond explicitly designed as an early warning mechanism and explicitly subordinated is unlikely to be the subject of successful lobbying for compensation by the investor. Nor should there be any likelihood of a spillover effect into the insolvency of the institutional investor inasmuch as the investor's holdings of such bonds would be transparent and as such kept within affordable bounds. Besides, if the investor were a foreign institution, as would be highly desirable, the loss would be exported.

On the other hand, holding the license of a local bank hostage to its ability to raise funds from possibly foreign institutions through subordinated debt at low interest may not be politically sustainable. Owners of small banks are typically a powerful political lobby. While such pressure can perhaps be resisted if it is a question of an isolated bank for which the preumption is that it really is in trouble, such pressure could be less easy to resist at the start-up phase of such a scheme (as indeed was the case in Argentina). In that case too, banks collectively may complain that their cost of funding is greatly increased and that they are placed at a competitive disadvantage.

\section{Market requirements}

It is sometimes asserted that requiring the issue of sub debt is infeasible in developing economies because of the lack of the relevant markets (Karacadag and Shrivastava, 2000). But this overstates the problem of market thinness. It is true that, even in advanced European economies, secondary markets for subordinated bank debt are very thin (Sironi, 2000, 2001a, b). But active secondary trading of these instruments is not necessary for the scheme to function. By requiring short maturities, the authorities can ensure that each bank is required to tap the primary issue market sufficiently frequently to ensure a regular flow of market information and discipline from the scheme. Indeed, in 
the case of Argentina, the primary market functioned well enough that the weakest banks were not able to issue. Covitz, Hancock, and Kwast (2003) show that in the United States as well, riskier banks were less likely to issue subordinated debt than their safer counterparts. ${ }^{6}$ Still, it is true that even the primary market may be difficult to establish at first, especially when all of the banks are seeking such funding, and that the issue of debt to foreign institutions could entail significant costs.

\section{Administrative requirements}

In some dimensions, the sub debt requirement scheme calls for very little administrative capacity. Thus, there is no need to assess the condition of the bank: all that is required in this dimension is to know the total assets or whatever the chosen the key for the sub debt requirement may be. The regulatory authorities do however need to verify two important and interlinked aspects: is the investor truly an independent and potentially well-informed institution, and has the risk been hedged by the investor through some form of explicit or implicit put back to the inside shareholders of the bank. It may not always be easy for the regulatory authorities in developing economies to verify such matters, though they are less likely to be a problem if qualifying investors are restricted to reputable international banks or institutional investors.

\section{Empirical experience on the magnitude of effect}

Listed subordinated bonds also have some signaling effect, and are responsive to risk in advanced economies (Evanoff and Wall, 2001, Morgan and Stiroh 1999, 2001, Sironi, $2000,20001 \mathrm{a}, \mathrm{b})$. But, even in advanced systems, bond markets are thin and illiquid and the price uncertainty tends to swamp the signal. Nevertheless, proposals for mandatory issues of subordinated debt to reputable external buyers do not depend on the presence of an active secondary market: employing short-term debt that needs to be rolled-over on a regular basis can be an adequate substitute.

Gropp, Vesala and Vulpes (2002) have examined the predictive ability of bank bond spreads in Europe, using downgrades to C or below as a proxy for "failure" since few banks actually fail in Europe; even though their study employs the rating agencies' "support ratings" as an indication of the degree to which a bank is considered "too big to fail," they find predictive power for the bond spreads only in the case of the UK.

There has been limited experience with mandatory subordinated debt to date - the Argentine experiment being effectively the only case and as that system came under the pressure that ended with the default of 2001, there was extensive forbearance on the requirement. The presence of subordinated debt on banks' books in other countries can, nevertheless be somewhat informative about potential features of their use (see Box on Lebanon).

\footnotetext{
${ }^{6}$ Importantly, they note that this creates a significant problem for researchers who are using secondary market spreads to test for market discipline; the absence of any evidence does not mean that the market is not exerting discipline, but rather that it already has, by preventing or discouraging weaker banks from issuing paper in first place.
} 


\section{Potential role of equity markets for disciplining banks}

\section{The mechanism}

Equity markets also monitor and directly discipline the insiders at listed banks. ${ }^{7}$ If the insiders are looting, or taking higher risks, this could show in the price of equity, directly affecting the wealth of the insiders and their ability to raise future capital, though not necessarily feeding through to interest rates demanded by depositors or bondholders. Unlike the situation for deposits, there is room for difference of opinion among informed investors: the pessimists will sell to the optimists. Shifts in the holding of informed insiders can also be informative though they are normally publicly disclosed and as such may in turn pass-through to the market price. A shortcoming of the equity price as a signal is that it prices-in both upside and downside prospects. An increase in the risk of failure may not lower equilibrium equity prices if it is also accompanied by some increased probability of higher return. Indeed, an increase in risk that is compensated by an increase in expected return will see equity prices rise rather than fall, provided the outside shareholders are confident that they will share proportionally in the gain and not be exploited by the insiders.

Bank equity can be seen as embodying the likely future value of the firms plus a put option at zero price. If the assumptions underlying standard option price theory are valid for the equity price, it is possible to invert such formulas, using information about, for example, the variance of equity prices, to arrive at a probability of default (cf. Laeven 2002). This is, in effect, a refinement of simpler "distance-to-default" measures, which compare equity prices to their standard deviation.

\section{Political economy}

Outside equity holders are less likely to be bailed out than any other category of stakeholder in a failing bank. Insiders, with their ability to spoil smooth intervention operations, are more likely to be insulated in such circumstances. This heightens the sensitivity of outside equity holders to information about the banks' prospects and enhances the potential role of the market price of equity as a signal of the bank's condition.

\section{Market pre-requisites}

But bank shares need to be listed if their market price is to be readily available. More and more banks are listed, and this can be the case even for some majority state-owned or foreign-owned banks. The effectiveness of the price discovery process is variable

\footnotetext{
${ }^{7}$ Saunders, 2001 even suggests that debt and equity market prices can theoretically provide equivalent information about the riskiness of a bank and that the equity market is in practice probably more effective, since the secondary debt market is thin - just a few players even in the United States - and probably not very efficient at pricing. This may be an extreme view, oversimplifying the problem of inferring the default probability from equity prices - arguably trickier (and requiring more additional information or assumptions) than doing so from the price of debt. In his comparison of equity and subordinated debt as mechanisms for providing market discipline, Saunders may be unduly neglecting the independence requirement of the sub debt schemes and the problem of insider looting if equity is closely held. But his observation that insiders at small banks may be self-serving in favoring mandatory debt issues over dilution of their equity is an astute one.
} 
depending, for example, on the openness of the stock market to international flows, and on whether the equities are cross-listed on a mature exchange.

\section{Empirical evidence}

The potential signaling role of equity prices is important and undervalued, even in relatively undeveloped markets. Thus for example, the "distance-to-default" measured from market prices of the equity of Thai banks predicted their difficulties in 1997 well before rating agency downgrades. ${ }^{8}$ The potential of equity prices to signal risk of failure before the East Asia crisis is also well illustrated by the synthetic exercise conducted by Bongini, Laeven and Majnoni (2002) who showed the superior forecasting ability of probability of default computed from an equity-price based option price model, not only relative to published ratings but also to a synthetic measure of risk of failure based on accounting data. ${ }^{9}$

Even if outside equity holders are unable to directly influence the decisions of insiders, movements in market prices do make recapitalization more costly for the insiders and represent a very transparent signal (Gropp, Vesala and Vulpes, 2002). Interestingly, evidence from Europe suggests that bank equity prices respond much more reliably to rating agency downgrades than do their bond prices (Gropp and Richards, 2001), perhaps due to a perception that the relevant banks - most of them large - are too big to fail and that bondholders are therefore unconcerned about risk. In the US, the indications are that bond and equity returns on bank holding companies usually co-move - the companies are not sufficiently near insolvency for interests of bond holders and equity holders to diverge much - except sometimes and these observations are, of course, of especial interest (Bliss and Flannery, 2001).

\section{Specialized information firms}

\section{The mechanism}

Auditors and rating agencies are the most relevant of the small group of specialist information firms assessing the condition of banks. Their incentives are not directly linked to the future value of the banks' securities, but instead depend on their reputation and accreditation, which are the source of their continuing profitability. Reputation arises because, regardless of who actually pays, the demand for the services of such firms depends on the degree to which they are perceived as trustworthy and reliable by the major users of the information they provide: equity and bond investors respectively. Both have long been used for regulatory purposes in the US (but not in most other advanced economies) with their usefulness in this role depending on their ability to retain the confidence of the regulator. There is clearly a rental or surplus involved in this regulatory usage, which can be lost if the raters become too generous in their ratings or when auditors acquiesce in over-optimistic accounts. In the developing country context

\footnotetext{
${ }^{8}$ Using the KMV methodology to compute default probabilities from equity price movements it can be shown that the debt of several Thai banks were at junk-bond levels at a time in 1997 while the rating agencies were still treating them as investment-grade (Saunders, 2001).

${ }^{9}$ Note however that equity-based risk measures are not correlated with bank deposit interest premiums (Opiela, 2001).
} 
however, the business model of the international ratings companies relies on global reputation rather than any regulatory requirements. Traditionally, auditors were chiefly responsible to the shareholders (especially in common law countries), though law may increasingly impose certain other responsibilities including reporting to the prudential supervisors.

\section{Political economy}

Because rating of banks is typically conducted by international firms, the process can be thought of as largely independent of national political pressures in the host country. It would be a different matter if rating agencies were brought in formally to the regulatory process inasmuch as they would require accreditation, which could suck them into compliance with political pressures. Auditing firms are usually accredited through a selfregulatory process, though there is a recent trend toward official regulation in several countries following recent US accounting scandals.

Table 1: Number of banks rated by Fitch in each developing country (October 2003)

\begin{tabular}{|c|c|c|}
\hline Sub-Saharan Africa & East Asia & Middle East \\
\hline Benin 1 & China 16 & \& North Africa \\
\hline Kenya 4 & Indonesia 14 & Egypt 9 \\
\hline South Africa 16 & Malaysia 11 & Jordan 3 \\
\hline & Philippines 14 & Lebanon 5 \\
\hline Eastern Europe & Thailand 19 & Morocco 5 \\
\hline \& Central Asia & Viet Nam 7 & Oman 3 \\
\hline Azerbaijan 1 & & Pakistan 5 \\
\hline Belarus 1 & Latin America & Saudi Arabia 9 \\
\hline Bulgaria 2 & \& The Caribbean & Tunisia 15 \\
\hline Croatia 4 & Argentina 6 & Turkey 29 \\
\hline Czech Republic 4 & Bolivia 1 & \\
\hline Estonia 2 & Brazil 50 & South Asia \\
\hline Georgia 1 & Chile 5 & Bangladesh 5 \\
\hline Hungary 8 & Colombia 5 & India 34 \\
\hline Kazakstan 7 & Dominican Rep. 5 & Sri Lanka 5 \\
\hline Latvia 5 & Ecuador 2 & \\
\hline Poland 12 & El Salvador 5 & \\
\hline Romania 5 & México 9 & \\
\hline Russia 30 & Panama 4 & \\
\hline Slovakia 7 & Trinidad \& Tobago 4 & \\
\hline Ukraine 3 & Uruguay 8 & \\
\hline Uzbekistán 1 & Venezuela 8 & \\
\hline
\end{tabular}

\section{Market pre-requisites}

Many of the ratings they provide are unsolicited and unpaid-for by the banks.

Nevertheless, it has apparently been profitable for several international ratings firms to rate the largest banks in upper-middle-income countries and in the largest of the lower- 
middle-income countries (for example, Fitch Ratings provide at least some form of rating for 439 banks in 50 developing countries - Table 1). By the same token, they may not be as well informed about market rumors and intangible measures of management performance as could nationals. The proposed use of rating agencies in (the so-called standardized approach to risk-weighting of) Basel risks may well prove to be an illustration of reliance on an invalid model of market forces and could even amplify risks (Honohan, 2001).

International reputation is also of some (limited) consequence for auditing firms, mainly through the potential of losing the affiliation to one or other of the major international groups.

\section{Empirical evidence}

There is a clear link between ratings and required yields on corporate bonds in advanced economies. The evidence on whether the linkage is a causal one is less unambiguous. Although some commentators have complained about the rather modest amount of staff resources assigned by the major rating agencies to individual companies or banks, there is evidence that they can uncover relevant non-public information as embodied in their ratings (cf. the evidence already cited by Gropp and Richards for European banks suggesting that rating agencies do provide valuable information for stockholders -though not for bondholders).

For developing economies, though, Richards and Deddouche (1999) find that ratings changes do not much influence equity prices of banks in developing economies 1991-98. If anything there were perverse effects. They conclude that ratings may not have conveyed much information in the sample period, casting some doubt on how useful they could be in helping regulators in developing countries. ${ }^{10}$

\section{Where Are the Environmental Preconditions in Place? Cross-Country Evidence}

Thus far, evidence concerning the effectiveness of the various flavors of market discipline, though strongly suggestive of a potential role in disciplining bank insiders in various contexts, is fragmentary both in terms of country coverage and in terms of the channels of effect examined. That risky banks may pay more for their sources of funds is hardly a discovery with earth-shattering policy implications. That the promulgation of a credible official blanket deposit guarantee may weaken this link is by now almost axiomatic. Ideally we would know which particular forms of market discipline are materially effective in different institutional environments and whether the adoption of

\footnotetext{
${ }^{10}$ The failure of ratings agencies to provide the slightest hint of several major individual institution failures is further illustrative of this perspective. For example, international analysts Salomon Brothers described Brazil's Banco Nacional in November 1994 as a "strong" bank which they believed would be a "long-term winner"; even as late as June 1995, less than five months before the deposit run that precipitated the bank's failure, Salomons recommended the shares as a "hold". A December 2002 Fitch report on the Dominican Banking System noted robust profitability and struck no note of caution, this just five months before the collapse due to fraud of Banco Intercontinental (Baninter) with losses amounting to over US\$2 billion or 15\% of GDP, followed by two other banking failures.
} 
discipline-relaxing policy stances makes a material difference. The needed evidence relates both to elements of the political and policy environment, which can act as a negative, discipline relaxing, force (for example by guaranteeing depositors or substituting state ownership for private) and the market and administrative institutional requirements (including legal and regulatory requirements).

In this section we show how these environmental aspects, relevant for the effectiveness of market discipline, can vary in practice from country to country, and show that although some aspects are correlated with GDP per capita, this is not the whole story.

\section{A. The environment - developing countries look different}

Contrasts between developing and advanced economies in the ownership structure of banks and other financial service providers, in the degree to which wealth and information can be concentrated among a relatively small business elite and the typical lack of scale that result in high information acquisition costs by those outside this elite group can drastically affect the relative effectiveness of each type of market discipline outlined in the previous section. We can illustrate this point by looking at a handful of specific country cases.

Take ownership: the importance of foreign strategic ownership and of government ownership varies substantially even for countries at the same overall level of development and of financial sophistication and these overall ownership structure issues are arguably among the most decisive in determining whether or not market discipline of whatever flavor - is likely to flourish.

Where banks are government-owned, the implicit depositor guarantee is strong, at least to the extent that the government itself is considered creditworthy. ${ }^{11}$ Banks in developing countries that are branches or subsidiaries of banks based in advanced economies will typically be subject more to the market discipline of their home country. Even where ownership is based in developing countries, host country market discipline will typically take a backseat to market discipline in the home country.

The extent to which many developing country banking systems are dominated by government or foreign-controlled banks is not widely recognized. The World Bank Regulation and Supervision Survey asks for data on the market share of majority government-owned banks and of majority foreign-owned banks. ${ }^{12}$ Analysis of the responses reveals that the median share, for developing countries, of these two categories taken together is 68.1 percent. Two in every five developing country banking systems have $85 \%$ or more in these two categories, and the lower quartile is over $94 \%$. The remainder $(31.9 \%$ for the median; $15 \%$ for two-fifths of countries and $6 \%$ for the lower quartile) represents an upper bound on the share of the banking system for which it is

\footnotetext{
${ }^{11}$ And this will differ depending on the currency denomination of deposits.

${ }^{12}$ Unless otherwise noted, data on banking, market and regulatory conditions in this and the following section is based on preliminary results from the second (2003) wave of the World Bank's Regulation and Supervision Survey in which data for 133 jurisdictions has now been collected.
} 
domestic market discipline that is chiefly relevant. (See Figure 1 and Table 2). To be sure, several of the jurisdictions covered in the survey with mainly foreign-owned banks are small offshore centers; nevertheless, the mean population size of countries dominated by government-owned and foreign-owned banks is larger than that of the other countries, so this is not simply a small country phenomenon. And the true figure for privatelycontrolled banks is undoubtedly lower, when account is taken, for example, of (i) banks with minority government stakes where the public sector's total shareholding (including other public sector institutions such as social insurance funds and other state-owned financial intermediaries) exceeds 50\%; (ii) joint venture banks with government and foreign partners between them holding more than $50 \%$; and (iii) effective control by government or foreign bank albeit with less than $50 \%$. The relevance of these cases becomes evident when we consider a few examples.

\section{Share of banking system not majority controlled by Government or foreign banks}

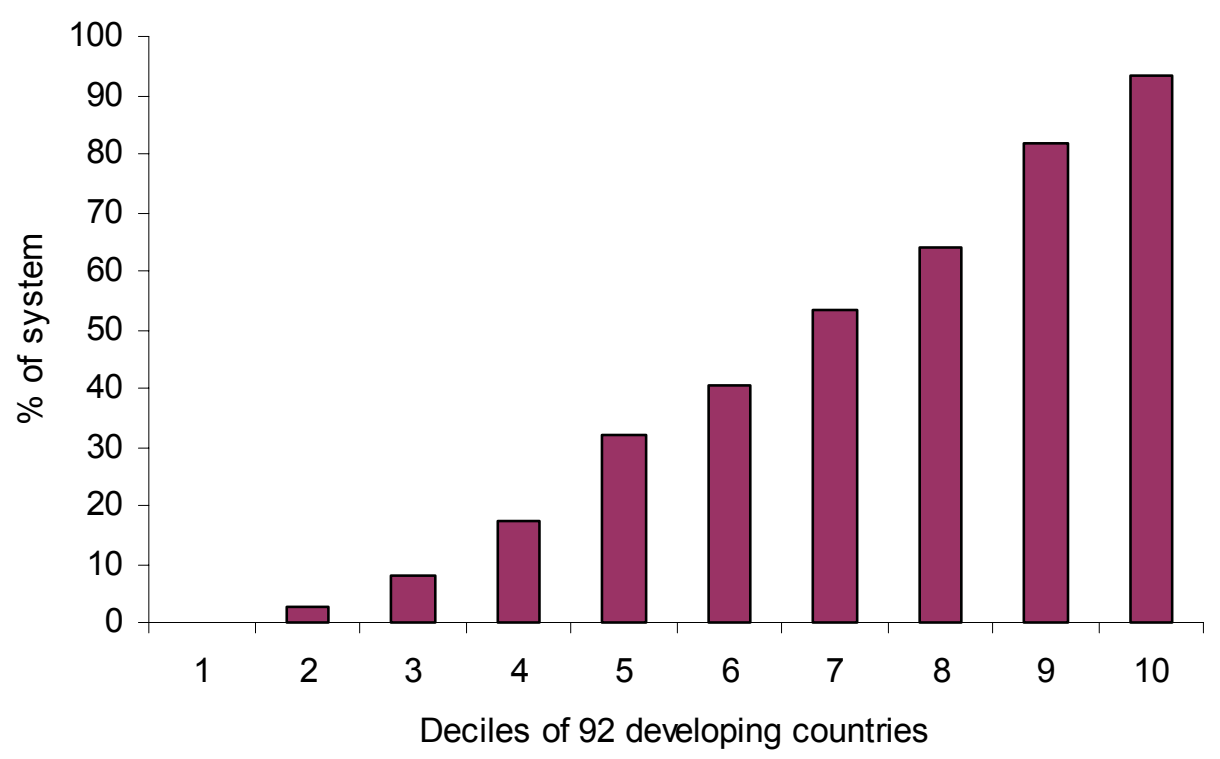

Figure 1(a): Share of banking system not majority controlled by government or foreign banks (Source: World Bank Regulation and Supervision Survey) 


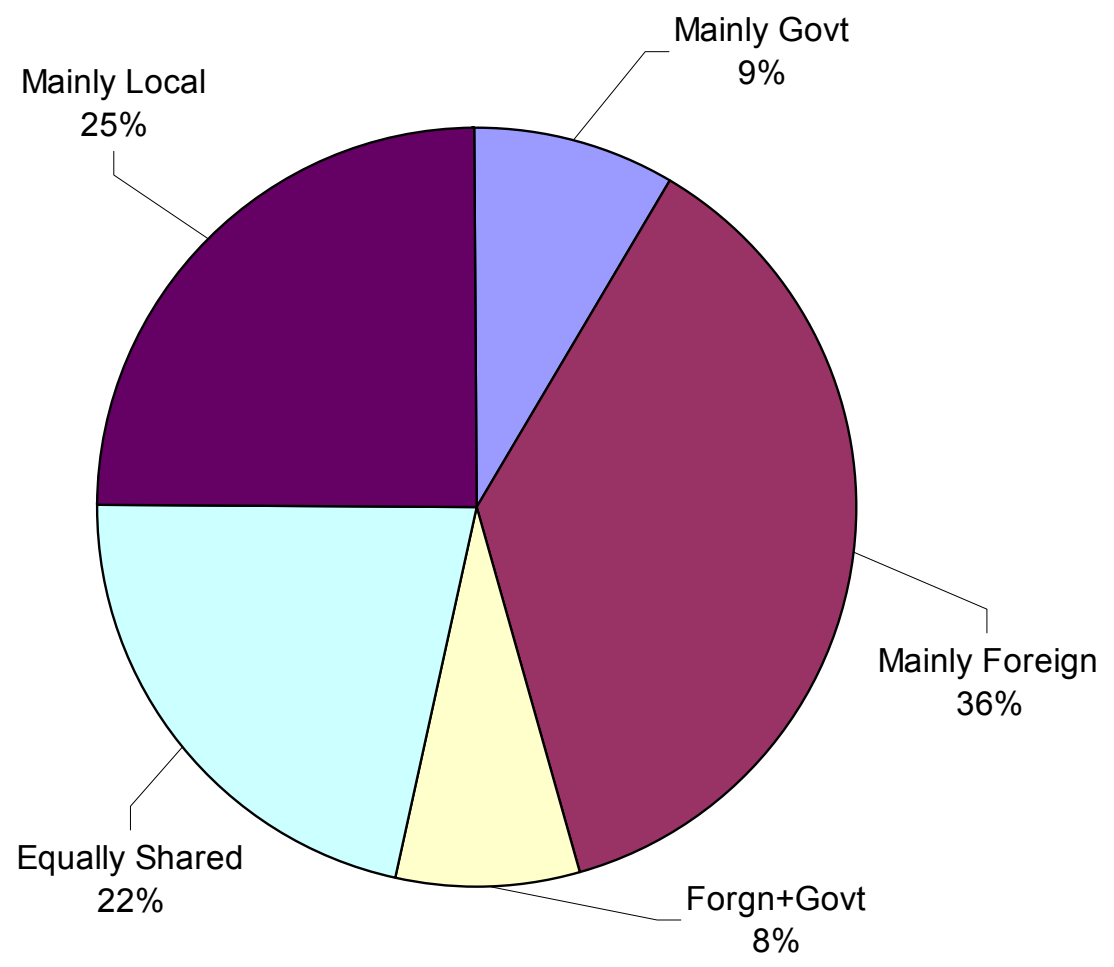

Figure 1 (b): Predominant ownership of reporting banking system (percent of reporting jurisdictions (Notes: Mainly government (foreign, private) means more than $60 \%$ of total assets in this form; Foreign+Government means these two together hold more than $70 \%$. Equally shared is a residual category. Source: World Bank Regulation and Supervision Survey) 
Table 2: Distribution of responding jurisdictions by predominant type of bank ownership (Not including high income economies)

\begin{tabular}{|c|c|c|c|c|}
\hline Mainly Govt & Mainly Foreign & Foreign+Govt & Equally Shared & Mainly Local \\
\hline Algeria & Aruba & Albania & Antigua & Anguilla \\
\hline Belarus & Bahrain & Montserrat & Argentina & Bolivia \\
\hline Bhutan & Belize & Pakistan & Armenia & Colombia \\
\hline Costa Rica & Botswana & Panama & Azerbaijan & El Salvador \\
\hline Ecuador & Br. Virgin Is. & Romania & Brazil & Guatemala \\
\hline Egypt & Bulgaria & Saint Kitts Nevis & Cameroon & Guyana \\
\hline India & Côte d'Ivoire & Uruguay & Chile & Honduras \\
\hline \multirow[t]{24}{*}{ Turkmenistan } & Croatia & & Ghana & Lebanon \\
\hline & Czech Republic & & Kenya & Liechtenstein \\
\hline & Dominica & & Kyrgyzstan & Malaysia \\
\hline & Estonia & & Macedonia & Mauritius \\
\hline & Fiji & & Moldova & Oman \\
\hline & Gambia & & Morocco & Philippines \\
\hline & Grenada & & Peru & Puerto Rico \\
\hline & Guinea & & Russia & Rwanda \\
\hline & Hungary & & Saint Lucia & Serbia \& Montenegro \\
\hline & Jordan & & Saudi Arabia & South Africa \\
\hline & Latvia & & Suriname & Sudan \\
\hline & Lesotho & & Tunisia & Thailand \\
\hline & Lithuania & & Venezuela & Trinidad \& Tobago \\
\hline & Madagascar & & & Turkey \\
\hline & Malta & & & Ukraine \\
\hline & Mexico & & & Zimbabwe \\
\hline & Namibia & & & \\
\hline & Poland & & & \\
\hline & Saint Vincent & & & \\
\hline & Seychelles & & & \\
\hline & Slovakia & & & \\
\hline & Swaziland & & & \\
\hline & Tonga & & & \\
\hline & Vanuatu & & & \\
\hline
\end{tabular}

Notes: Mainly government (foreign, private) means more than $60 \%$ of total assets in this form; Foreign+Government means these two together hold more than $70 \%$. Equally shared is a residual category. Source: World Bank Regulation and Supervision Survey 
Several countries are still dominated by state-owned banks. Examples are China, Egypt and Iran. In China the state-owned banks remain dominant, though a vigorous expansion of non-state and foreign-owned banks could erode this dominance over time. Nevertheless, the foreign-owned banks are likely to remain niche players, and the unrivalled branch network of the state-owned banks means that they are sure to remain central for the foreseeable future. Despite the widely canvassed view that recent recapitalizations have been insufficient to bring the true capital adequacy of the banks up to regulatory standards, there is an implicit guarantee attached to the state banks probably in this case extending even to their foreign and interbank obligations - that greatly limits depositor discipline. Certainly deposit growth has remained strong and the deposit/GDP ratio has continued to grow steadily since the mid-1990s, now reaching levels unknown elsewhere (aside from some small offshore financial centers). Information agencies can be informative on the underlying strength of the banks; thus, although the six internationally rated Chinese state banks reach the sovereign ceiling rating for China (reflecting TBTF), the agencies also offer financial strength ratings of between $\mathrm{D}$ - and $\mathrm{E}$ for the state-owned banks. Any foreign creditors who may distrust the implicit government guarantee thus receive a clear message from the ratings agencies. As far as the non-state owned national banks are concerned, there might be a weaker sense of implicit guarantee. To be sure, depositors even in the high-profile 1998 failures of Gitic and the Hainan Development Bank were made whole as to their capital (though other creditors lost out, and apparently not all depositors received all interest due) this has not been through either a formal deposit insurance scheme or a national bail-out, but was organized at least in part by regional governments. Moreover, there are reports of failures at smaller institutions from which depositors have been unable to recover their deposits. Thus, although most of the nationally-owned banking institutions do have public entities as controlling shareholders, there is some scope for depositor discipline. Furthermore, several of the city commercial banks have stock market listings and as such may be subject to a degree of outside shareholder discipline. The fact that the stateowned banks have lost market share to the newcomers can, from the perspective of market discipline, be interpreted in different ways. Most plausibly it suggests weak market discipline with regard to prudential aspects: the stronger implicit government guarantee counting little against a more attractive package of services provided by newcomers.

In Iran, the main banks were nationalized over twenty years ago and operated under relatively tight controls lending to the largely state-owned economy. Their reported profitability is very low, and questions have been raised in the media about the adequacy of their capital. ${ }^{13}$ Only recently have a handful of private banks been licensed and they operate on a very small scale. Likewise, there is no onshore branch or subsidiary presence of foreign-owned banks - though there are several representative offices. An implicit government guarantee is understood to hold for all of the banks, at least so far as their national obligations are concerned (the six main banks also have relatively sizable foreign operations). Effectively it would appear that all of the possible channels of

\footnotetext{
${ }^{13}$ Although the fact that all banks operate in accordance with Islamic banking principles complicates the question of capital ratios, in practice accounting for capital is done on conventional western lines.
} 
market discipline are shut in Iran. But there will evidently be a heightened need for market discipline if the relatively recent liberalization of lending is indeed to be followed, as is stated policy, by an extensive bank privatization program (there are reports that Saderat, one of the large banks, could be fully privatized within months).

Egypt presents a rather different picture, though one that is also in gradual transition. Here too, four state-owned commercial banks dominate, with about 60 percent of the deposit market and rather less of loans. Privatization of these four banks is a long-term objective, with the authorities relying for the present on having replaced top management across the board in order to achieve improvements in efficiency and in lending performance. The remainder of the system is divided fairly equally between (i) those controlled by foreign banks; (ii) joint venture banks with majority state-control, though having some foreign strategic bank shareholders and (iii) banks without a controlling shareholder. The latter still account for little more than 10 percent of the system, with the largest single bank in this category having less than 5 percent. The four state-owned banks and a handful of others (see Table 1) are internationally rated (with financial strength ratings of between $\mathrm{E}+$ and $\mathrm{D}+$ for the state banks, $\mathrm{D}+$ to $\mathrm{C}$ - for the other three). 13 banks are listed on the stock exchange. Egypt can thus be seen as on the threshold of an era where market monitoring will become both more necessary and possible.

At the other end of the spectrum lie countries such as Mexico, whose banking systems are dominated by foreign-controlled banks. Mexico has seen a rapid ownership transformation in the last few years since the Tequila crisis of 1994-95. Restrictions that formerly prevented foreign banks from controlling large banks (any one accounting for more than $6 \%$ of the system) were removed in 1999 . This unleashed a wave of mergers and acquisitions in 2000-2, following which only five big commercial banks now remain, and all but one is controlled by a large international bank. These are Banamex, controlled by Citicorp; Bancomer, controlled by Spain's BBVA; Bital, controlled by HSBC; and Serfin, now controlled by Santander. The Monterrey-based group controlling the fifth, Banorte, has a listing and is rated by the international agencies. The other large banks are also rated with support ratings related to their foreign parent's strength. Foreign control of the commercial banking system, at well over 80 percent, is easily the highest in Latin America. Thus, the role of domestic market discipline is largely confined to a rather small segment of the banking system. Indeed, as is well known, shareholder prudence following events of 1994-95 has been reflected in a dramatic shrinkage of credit from the banking system: total institutional credit to the nonbank private sector shrank from 62 percent of GDP in 1994 to 31 percent in 2001, fully accounted for by the fall in bank credit alone from 45 percent of GDP to 14 percent.

Interestingly, even in the presence of blanket deposit insurance in the wake of the 199495 banking crisis, there did seem to be some market discipline at work. As is true in many countries, a large share of deposits in Mexico were owned by firms, and many of these firms needed to have the assurance that trade credit would be available to them. Even if the government guarantee on their deposits should have assured depositors, in fact there was anecdotal evidence that some firms began moving their business, deposits included, to the stronger banks in order to ensure that their access to trade credit would be 
there when they needed it. Although banks can stay open with deposit insurance guarantees, if they have a large share of nonperforming loans, they may need to allocate an increasing share of new credit to keep these loans current, potentially depriving their good clients of access to finance when they need it.

There still are, of course, a significant number of developing countries where nationallyowned or widely held banks dominate the system. Examples here would be Argentina and Lebanon.

Argentina's banking system is an intermediate case with government, foreign banks, and local concerns, controlling roughly equal shares of the system. Famous for having introduced such regulatory innovations as a requirement for banks to issue subordinated debt to independent institutional shareholders, as well as for the dramatic collapse of the fixed exchange rate system, Argentina's banking system has, as mentioned, previously been examined for evidence of market discipline in deposits. Data on the average interest rate paid, as well as on the market share of the largest twelve banks in Argentina does not, however, reveal either a clear pattern of higher interest rates, or a loss of deposits, by those banks reporting higher loan-delinquency experience in the months running up to the collapse of the system in 2001 (cf. Martinez-Peria and Schmukler, 2003). This tends to confirm that the collapse was a systemic one, driven largely by macroeconomic and government induced factors, rather than by deficient management of individual banks.

Essentially all of Lebanon's banks are privately owned (though it is interesting to find that the fourth largest, Banque de la Mediterranee is owned by a holding company understood $^{14}$ to be owned by the current prime minister, Rafik Hariri). Despite recent consolidation the market is not concentrated and has a Herfindahl index of about 600 (indicating concentration equivalent to the market being divided among 16 equal-sized banks). Four of the six largest banks are understood to be controlled by local families. The largest foreign-controlled bank is the fifth ranked Banque-Libano Francaise, of which $51 \%$ is owned by Indosuez of France. In total, there are ten other foreign-owned banks - three of them in the top ten by assets - of which six from Arab countries. Five of the banks, including three of the five largest, have a listing on the Beirut stock exchange. Additionally three of the largest banks have issued GDRs, and these GDRs have in turn been listed in Beirut (in one case even though the bank in question does not have a primary listing there, see Box). Preference shares have also been issued and sold acrossthe-counter by four large banks and the three largest have also issued ten-year subordinated bonds denominated in US dollars and listed in London or Luxembourg. Here, then is an economy where the main channels of market discipline are open, both for domestic investors and depositors as well as an important potential role for foreign investors in the GDRs and externally listed debt of the banks. The relatively high monetization of the Lebanese economy, including sizable deposits by non-residents and temporary expatriates from Lebanon, and the high degree of deposit dollarization, which has remained around two-thirds of the total for several years, despite the fixed peg with the US dollar maintained through this period, suggests that deposit holdings are well

\footnotetext{
${ }^{14}$ This and other ownership indications about Lebanese banking are drawn mainly from analyst reports by rating agency Capital Intelligence.
} 
above the minimum transactions balances and as such depositors will tend to be alert to warning signs. There is a deposit insurance scheme, but its coverage (about USD 3300) and assets (about 1.4\% of total banking assets) are relatively small, and payout in the past has been slow. More to the point, the degree to which implicit deposit insurance applies on a large scale is limited by the consideration that the government is by far the largest creditor of the banking system. Yet, with a population of just 4 million Lebanon is a small country with a small elite business community and, despite their impressive performance, its banks too are small, limiting the resources which rating agencies can justify expending when researching their ratings.

\section{B. Preconditions - By flavor of discipline and income level}

We can attempt to quantify some of the preconditions for market monitoring, using in particular data from the second (2003) wave of the World Bank's regulatory survey (of which the first wave results are discussed in Barth et al, 2001, 2003) and combining this with other sources of information. We begin with updated information on the overall "private sector monitoring" index proposed by Barth, Caprio and Levine and summarizing the extent to which the private sector is empowered to exercise market discipline. This private sector monitoring index captures elements of the preconditions for each of the flavors of market discipline we have discussed. ${ }^{15}$
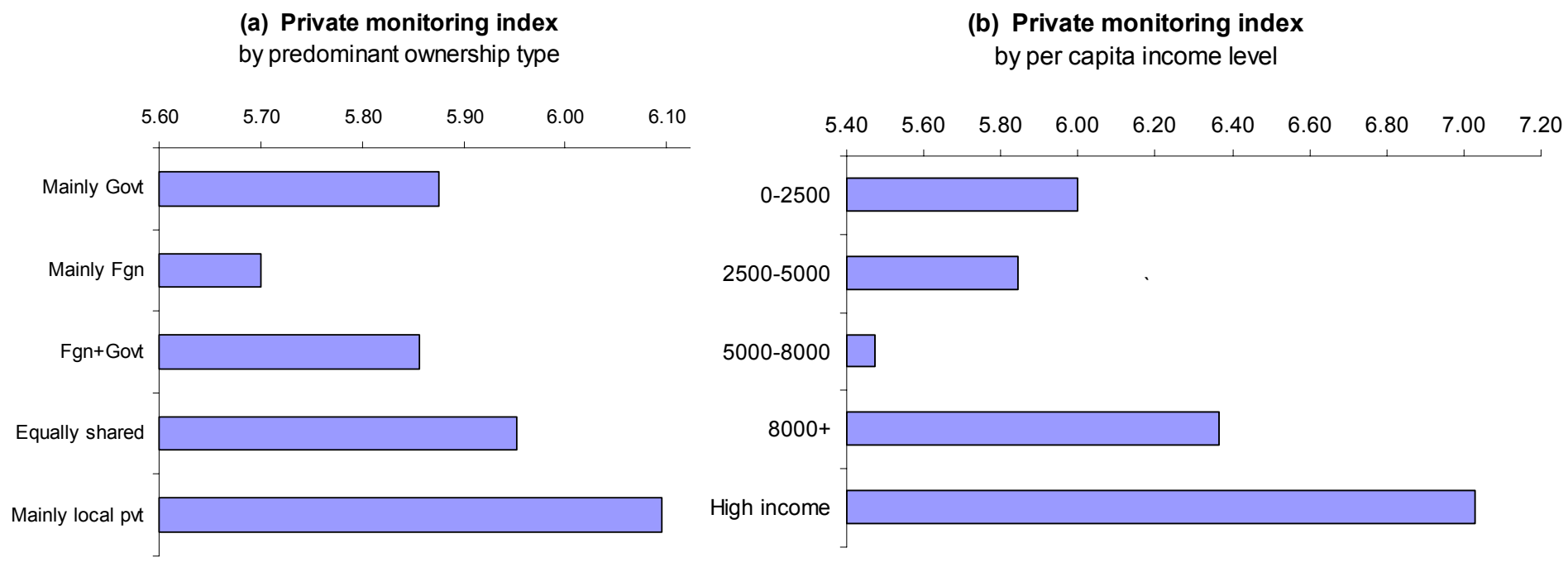

Figure 2: Private Monitoring index and (a) predominant type of ownership; (b) per capita income level (PPP)

(Source: World Bank Regulation and Supervision Survey; for definition of predominant type of ownership see note to Table 2)

\footnotetext{
${ }^{15}$ The methodology for computing the summary index of private monitoring is as described in Barth, Caprio and Levine, 2001. As such it covers bank accounting rules, auditing and disclosure requirements, rating of banks, deposit insurance and subordinated debt.
} 
Unsurprisingly, we find that this index is higher, the higher the fraction of the banking system that is in local private hands (Figure 2a). In other words, those countries that have predominantly government-owned or foreign-owned banking systems have lower values of this index. This can be seen as fitting, to the extent that their banks don't need local market discipline. On the other hand, there is no apparent correlation between the market monitoring index and per capita income (Figure 2b). Yes, the high income economies have a higher average value than the developing countries as a group, but within the latter, the average value actually declines as one moves from the lowest income categories. Overall, then, data for the private sector monitoring index does not suggest a systematic tendency for the preconditions for market discipline to be more absent at lower income categories.

Barth, Caprio and Levine (2003) found that the private monitoring index was negatively correlated with a variety of measures of banking risk. Here we use just one additional (inverse) measure of risk, De Nicoló's $Z$ (cf De Nicoló et al., 2003). This is computed for each country as the average ratio for the largest banks of accounting capital to the standard deviation of bank earnings. The bivariate correlation between the private monitoring index and the risk measure $Z$ is quite strong (see Table 5, equation 1.1 below-lower values of $Z$ imply higher risk), though the relation is not very robust as will be shown below.

More speculatively, we can attempt to isolate components of the environment that are particularly relevant to each of the main flavors of market discipline. Table 3 proposes an allocation. For example, the key variable for depositor monitoring is absence of official depositor protection. As indicated in the Table 3, depositor discipline would also be particularly facilitated by a better information environment among the largest depositors, here crudely approximated by population size (the smaller the better). Likewise, better accounts, and accountability of bank management ${ }^{16}$ is also assigned as likely to be particularly relevant to depositor monitoring of bank management.

Turning to discipline by equity and bond holders, the percentage of private banks that are listed will be especially important. Finally, for information specialists to be effective, it will be necessary for the banks to be rated (we count how many of the largest ten banks are rated) and for adequate auditing requirements (we measure this by asking if external audit by a certified auditor is compulsory).

The mean values for these variables, as measured using data from the Regulation Survey, are shown in Figures 3 and 4 and in Table 4.

Using data on these variables in regressions explaining allocation, we note that the key specific preconditions for depositor discipline and that provided by equity holders are again correlated with $Z$ and with the correct sign (Table 5, regressions 1.2 and 1.3). The presence of a formal deposit insurance scheme is used for depositor discipline, and an

\footnotetext{
${ }^{16}$ Here measured by an index whose value is higher depending on whether interest accrued but unpaid is excluded from bank earnings, whether consolidation of group accounts is required, and whether bank directors are legally liable for misleading information
} 
approximate ${ }^{17}$ share of the privately-owned banking system that has a stock exchange listing for the equity holders. On the other hand, the number of rated banks is not significant (regression 1.4), in line with our expectation that the role of specialized information firms may be a weaker channel, especially for a sample that includes such a high proportion of developing countries. Of the available proxies other institutional indicators proposed in Table 3, only the size variable (population) proves to be significant (Table 5, regression 1.7) and it has the expected sign: small countries performing better.

It needs to be noted, of course, that these bivariate correlations are not very robust, and as such can be taken as suggestive only. This is not surprising, given the very indirect character of the proxies employed. In particular, GNP per capita is an even stronger (inverse) predictor of banking risk (Table 5, regression 2.2), and it displaces the private sector monitoring index - though this remains close to significant at the 10 percent level when included. ${ }^{18}$ More important, there is no evidence of an interactive term (Table 5, regressions 2.3 and 2.5): there is no indication of a systematically different private sector monitoring index is equally effective in reducing risk in rich and poor countries.

Table 3: Suggested assignment of preconditions to different sources of discipline Type of precondition: Market and administrative Political and policy stance institutions

Source of discipline

\begin{tabular}{|c|c|c|}
\hline Depositors & $\begin{array}{l}\text { Accountability of bank management } \\
\text { Size of country (small) }\end{array}$ & Deposit protection (low) \\
\hline Equit & Percentage of private banks listed & Government ownership share (low) \\
\hline Information firms & $\begin{array}{l}\text { Number of banks rated } \\
\text { Auditing requirements }\end{array}$ & Foreign ownership share (high) \\
\hline
\end{tabular}

Table 4: Indicators of selected preconditions by income level (Developing countries, mean values)

\begin{tabular}{|c|c|c|c|c|}
\hline Income level & $<\$ 2500$ & $\$ 2500-\$ 5000$ & $\$ 5000-\$ 8000$ & $>\$ 8000$ \\
\hline Accountability of bank management & 2.71 & 2.72 & 2.72 & 2.91 \\
\hline Small size of country & 11 & 8 & 10 & 4 \\
\hline Percentage of private banks listed & 0.33 & 0.45 & 0.50 & 0.69 \\
\hline Number of banks rated & 0.6 & 3.8 & 2.0 & 4.1 \\
\hline Auditing requirements & 0.72 & 0.78 & 0.63 & 0.82 \\
\hline No deposit protection & 0.56 & 0.26 & 0.32 & 0.09 \\
\hline Government ownership share & 0.09 & 0.29 & 0.25 & 0.13 \\
\hline Foreign ownership share & 0.43 & 0.33 & 0.46 & 0.52 \\
\hline
\end{tabular}

Note: For definition of variables employed see note to Table 5.

Source: World Bank Regulation and Supervision Survey, except income level (measured in PPP, 2001) and size (population in millions): World Development Indicators.

\footnotetext{
${ }^{17}$ Because of issues of aggregation and double counting, this measure is a fairly rough approximation. See note to Table 4 for its construction.

${ }^{18}$ Several authors (La Porta et al. 1999, Barth, Caprio and Levine, 2001) have previously noted the difficulties presented by including GNP per capita, potentially an endogenous variable, in regressions along with determinants of banking risk. Clearly there is a risk that the independent role of such determinants as the private monitoring index could be masked by such inclusion.
} 
Assessing the degree to which these preconditions are satisfied in different countries, it proves not to be the case that the preconditions are systematically less present in poorer countries.

Take depositor discipline. As already mentioned, depositors do require basic disclosures of accounting information and for the bank managers to be accountable for the accuracy of this information. Our summary variable for bank management accountability ${ }^{19}$ can vary from 0 to 3 , though most countries score 2 or 3 , and we find (Figure 3 ) that the variation of the mean value here by countries in different income classes is relatively small, going from 2.71 in the lowest quartile of developing countries to 2.77 in high income countries (upper middle-income countries score highest: 2.91 on this measure). Additionally however, there is the point that informal sources of depositor information are likely to be much better where the number of large depositors, whether individual or corporate, is small (cf. the Scottish analogy, above). While we do not have systematic data on the number of large depositors for many of our sample countries, it is clearly an offsetting positive factor that strengthens potential depositor discipline in the poorer countries on average. The negative pre-requisite is the absence of deposit protection. Using the simple existence of an explicit deposit insurance scheme as a proxy for this, we find that fewer of the poor countries have such schemes and to that extent the negative preconditions are more often present in poor countries (Figure 3).

Turning to discipline by debt and outside equity holders, considering the availability of stock market listings to be an indicator of one precondition for this kind of discipline, we see (Figure 3 ) that the estimated share of total banking assets in listed entities does seem to increase as income levels go up, and indeed there is a significant positive correlation $(\mathrm{R}=0.27)$ between this index and per capita GNP. However, when the percentage of total assets in listed firms is expressed as a proportion of banking assets not in government or foreign bank hands, the correlation becomes insignificant $(\mathrm{R}=0.18)$. Once more, then, the positive preconditions are not systematically weaker in poor countries.

The role of rating agencies does appear to be greater in rich countries. The number of rated banks increases significantly with per capita income, even when normalized by the share of non-government, non-foreign bank-owned banks in the system.

\footnotetext{
${ }^{19}$ This again follows the definition of Barth, Caprio and Levine and includes treatment of interest accrued but not received, existence of consolidated accounting for groups and legal liability of directors.
} 

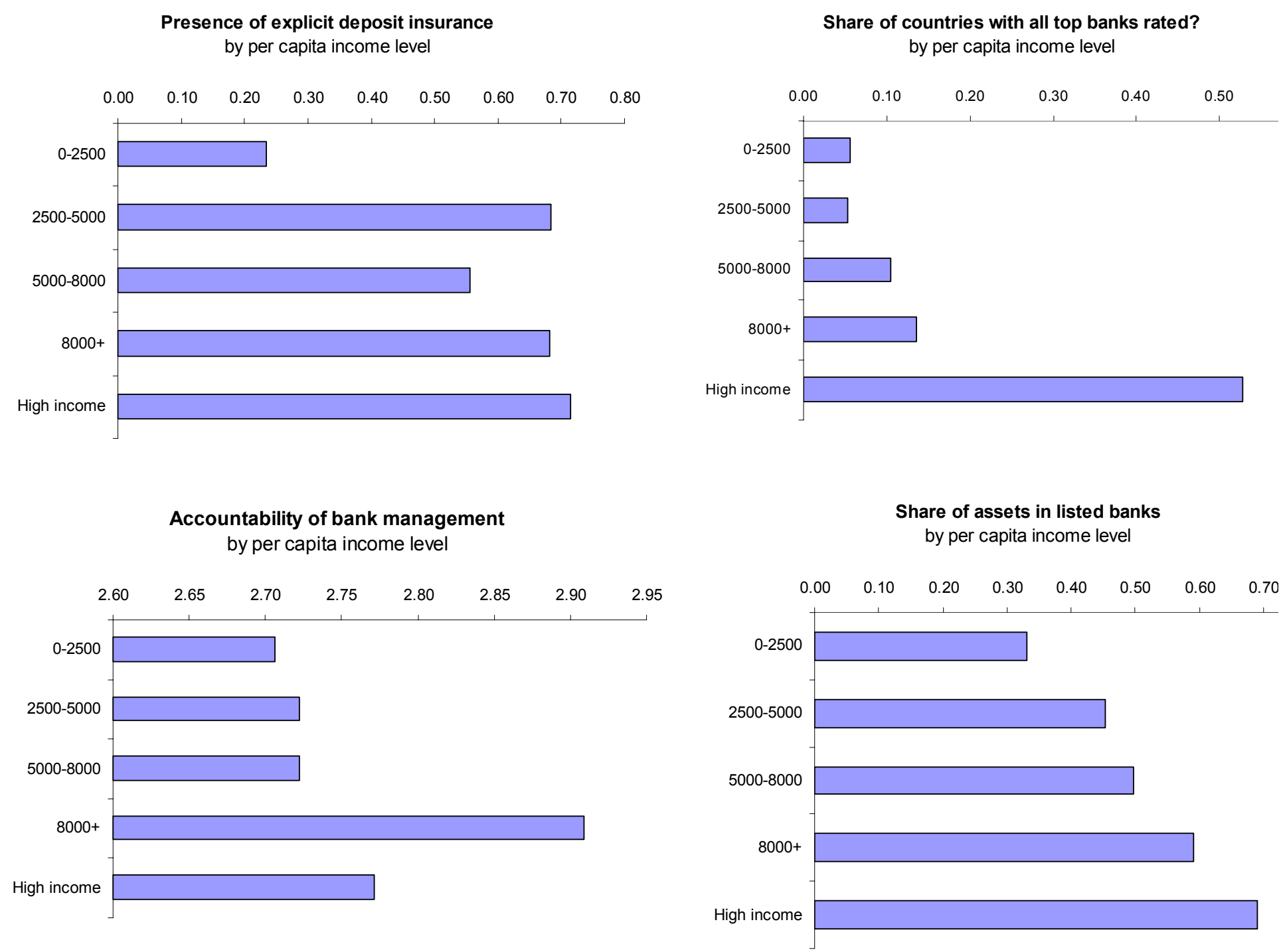

Figure 3: Selected indicators of market discipline preconditions by per capita income level (PPP), group means

(Source: World Bank Regulation and Supervision Survey)

Thus, when the data, fragmentary though it is, is interpreted through this prism, we can find surprisingly little evidence of systematic difference in the extent to which most positive and negative prerequisites for market discipline are present as between poor and rich, large and small countries. To be sure, systemic crises caused by macroeconomic, exchange rate or fiscal instability tend to swamp the discriminating function of the market as between banks that are soundly-run and the rest, and these events are more prevalent in poor and small economies. 
Presence of explicit deposit insurance

by predominant ownership type
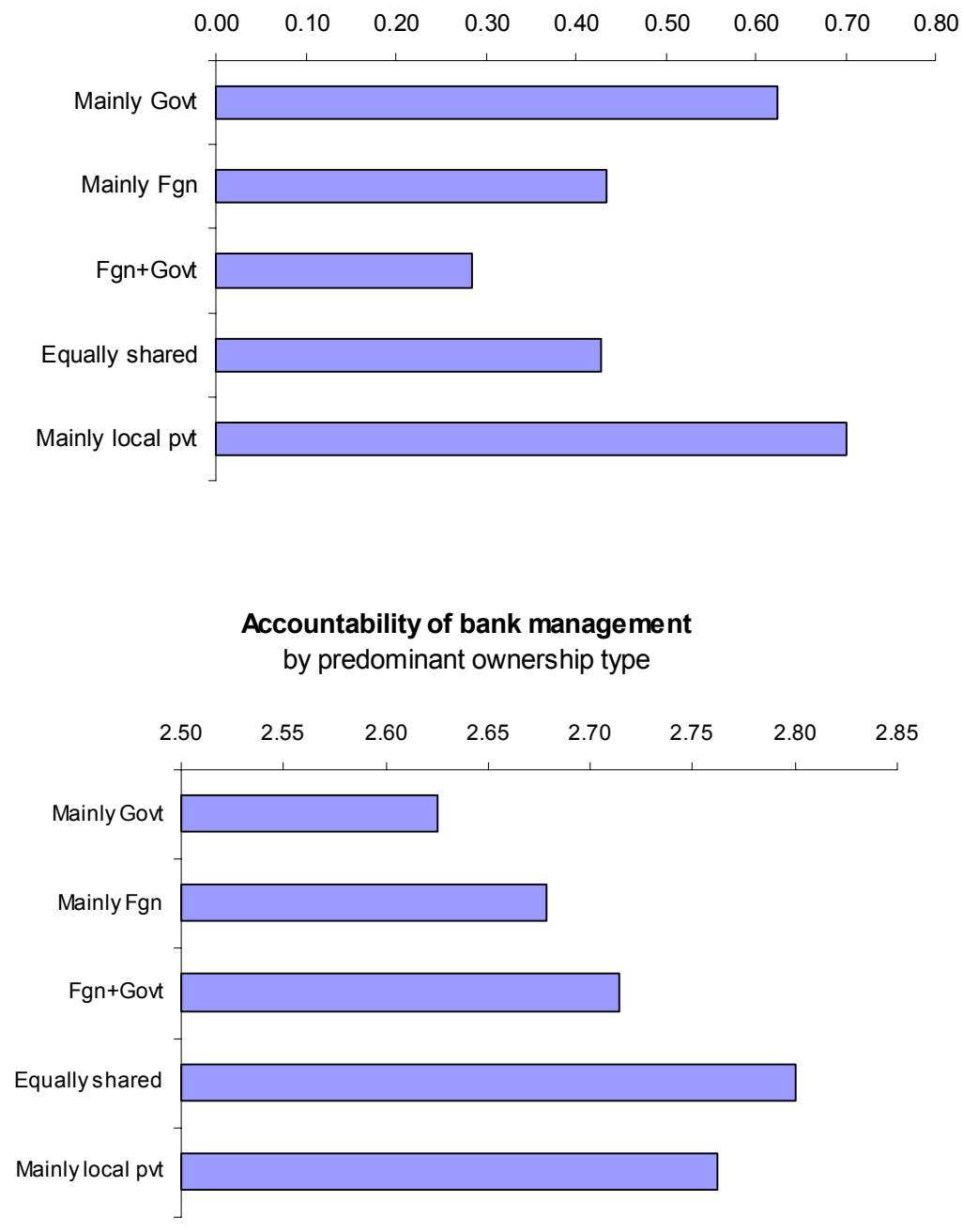

Share of countries with all top banks rated by predominant ownership type
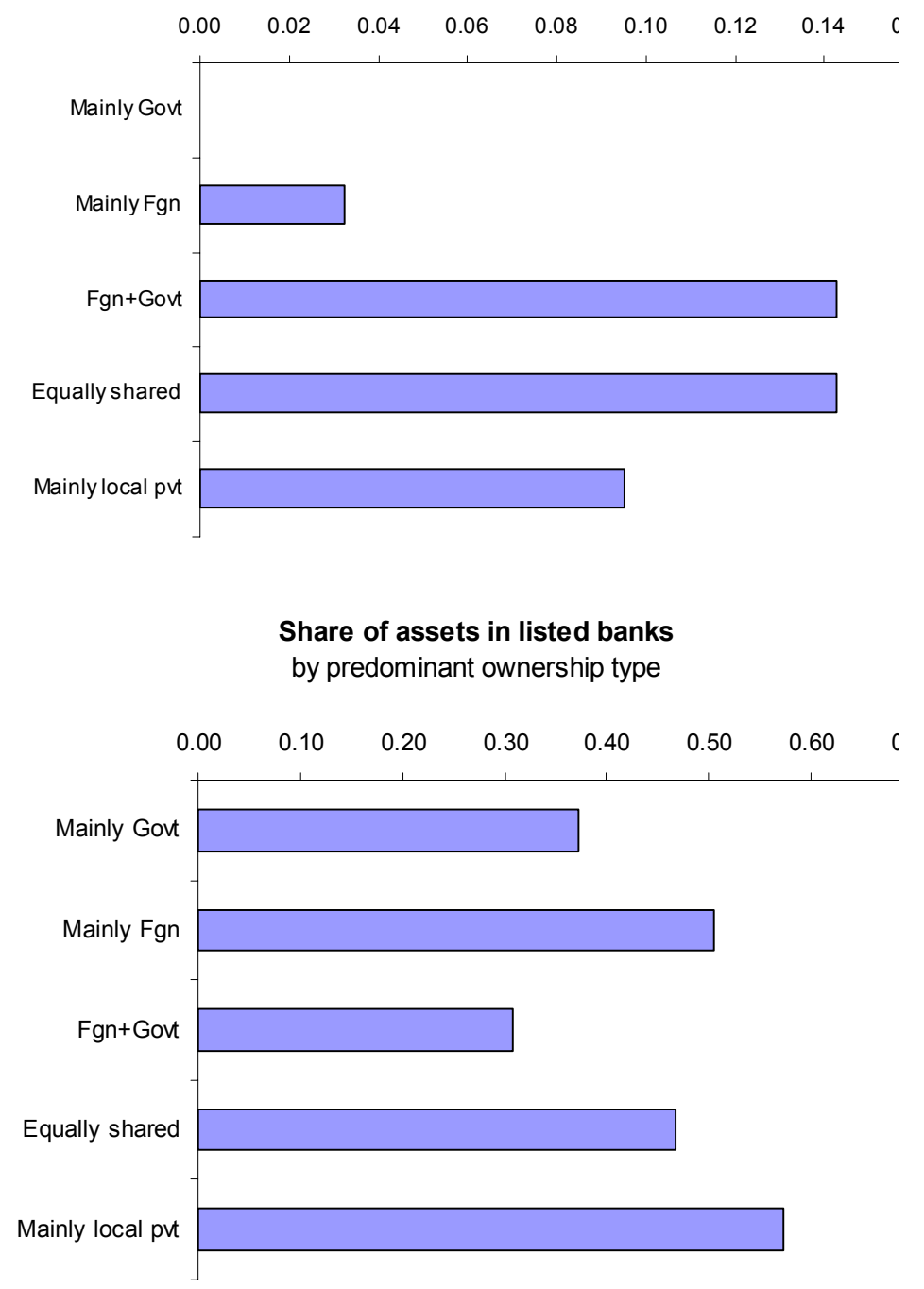

Figure 4: Selected indicators of market discipline preconditions by predominant ownership of banks, group means

(Source: World Bank Regulation and Supervision Survey; for definition of predominant type of ownership see note to Table 2) 
Table 5: Regression results

(i) Correlation of banking risk with the preconditions for different flavors of market discipline

\begin{tabular}{|c|c|c|c|c|c|c|c|c|c|c|c|c|c|c|}
\hline \multirow{2}{*}{$\begin{array}{l}\text { Equation: } \\
\text { Dependent var. } \\
\text { Explanatory var. }\end{array}$} & \multicolumn{2}{|c|}{$\begin{array}{c}1.1 \\
\text { Bank risk Z }\end{array}$} & \multicolumn{2}{|c|}{$\begin{array}{c}1.2 \\
\text { Bank risk Z }\end{array}$} & \multicolumn{2}{|c|}{$\begin{array}{c}1.3 \\
\text { Bank risk Z }\end{array}$} & \multicolumn{2}{|c|}{$\begin{array}{c}1.4 \\
\text { Bank risk Z }\end{array}$} & \multicolumn{2}{|c|}{$\begin{array}{c}1.5 \\
\text { Bank risk Z }\end{array}$} & \multicolumn{2}{|c|}{$\begin{array}{c}1.6 \\
\text { Bank risk Z }\end{array}$} & \multicolumn{2}{|c|}{$\begin{array}{c}1.7 \\
\text { Bank risk Z }\end{array}$} \\
\hline & Coeff. & $\mathrm{t}$-Stat & Coeff. & $\mathrm{t}$-Stat & Coeff. & t-Stat & Coeff. & t-Stat & Coeff. & $\mathrm{t}$-Stat & Coeff. & t-Stat & Coeff. & t-Stat \\
\hline Constant & -1.77 & 1.3 & 2.63 & $8.9 * * *$ & 1.70 & $3.3 * * *$ & 2.35 & $3.4 * * *$ & 1.04 & 0.6 & 6.02 & $2.5^{* *}$ & 3.84 & $8.5 * * *$ \\
\hline Private monitoring index & 0.712 & $3.4 * * *$ & & & & & & & & & & & & \\
\hline No deposit insurance & & & 1.26 & $2.1^{* *}$ & & & & & & & & & & \\
\hline Listed $\%$ of pvt banks & & & & & 2.35 & $2.6^{* *}$ & & & & & & & & \\
\hline Number banks rated & & & & & & & 0.115 & 1.2 & & & & & & \\
\hline Bank accounts & & & & & & & & & 0.680 & 1.1 & & & & \\
\hline Auditing & & & & & & & & & & & -3.12 & -1.3 & & \\
\hline Population size $(\log )$ & & & & & & & & & & & & & -0.374 & $2.4 * *$ \\
\hline $\mathrm{d} / \mathrm{NOBS}$ & 0.125 & 85 & 0.052 & 85 & 0.082 & 76 & 0.029 & 48 & 0.015 & 49 & 0.020 & 48 & 0.066 & 85 \\
\hline Adjusted R-squared & 0.114 & & 0.040 & & 0.070 & & 0.008 & & 0.003 & & 0.008 & & 0.054 & \\
\hline S.E. of regr./DW & 2.27 & 1.95 & 2.36 & 1.81 & 2.38 & 1.72 & 2.57 & 1.23 & 2.42 & 1.83 & 2.40 & 1.81 & 2.34 & 1.64 \\
\hline Log likel./Method & -189.1 & LS & -192.6 & LS & -172.8 & LS & -112.3 & LS & -192.3 & LS & -194.0 & LS & -191.9 & LS \\
\hline
\end{tabular}

(ii) Interaction of index of private market discipline with per capita income and ownership structure in affecting banking risk

$\begin{array}{lllllll}\text { Equation: } & 2.1 & 2.2 & 2.3 & 2.4 & 2.5 & 2.6\end{array}$

Dependent var. Bank risk Z $\quad$ Bank risk Z Bank risk Z Bank risk Z Bank risk Z Bank risk Z

\begin{tabular}{|c|c|c|c|c|c|c|c|c|c|c|c|c|}
\hline Explanatory var. & Coeff. & t-Stat & Coeff. & t-Stat & Coeff. & t-Stat & Coeff. & t-Stat & Coeff. & t-Stat & Coeff. & t-Stat \\
\hline Constant & -1.77 & 1.3 & 1.64 & $4.2 * * *$ & -0.543 & 0.4 & 1.613 & $4.2 * * *$ & 2.12 & 0.8 & 1.03 & $2.0^{*}$ \\
\hline Private Monitoring Index & 0.712 & $3.4 * * *$ & & & 0.359 & 1.6 & & & -0.058 & 0.1 & & \\
\hline GNP per cap (x 100) & & & 0.817 & $3.5^{* * *}$ & 0.708 & $3.0 * * *$ & & & -1.154 & 0.7 & 0.652 & $2.4^{* *}$ \\
\hline PvtMon x GNP p.c. & & & & & & & 0.124 & $4.0^{* * *}$ & 0.281 & 1.2 & & \\
\hline PvtMon x Privatebanks & & & & & & & & & & & 0.243 & $2.0^{*}$ \\
\hline R-squared / NOBS & 0.125 & 85 & 0.138 & 80 & 0.167 & 80 & 0.169 & 80 & 0.181 & 80 & 0.168 & 72 \\
\hline Adjusted R-squared & 0.114 & & 0.127 & & 0.141 & & 0.159 & & 0.149 & & 0.144 & \\
\hline S.E. of regr./DW & 2.27 & 1.95 & 2.17 & 1.46 & 2.19 & 1.45 & 2.14 & 1.44 & 2.15 & 1.44 & 2.22 & 1.38 \\
\hline Log likel./Method & -189.1 & LS & 174.7 & LS & -168.1 & LS & -173.3 & LS & -172.7 & LS & -158.1 & \\
\hline
\end{tabular}

Note: The dependent variable bank risk is measured by De Nicoló's $Z$, which is the average for banks in each country of each

bank's return on assets plus accounting capital all divided by the standard deviation of returns (cf. De Nicoló et al, 2003). Data

kindly provided by Gianni de Nicoló.

Except where mentioned, the explanatory variables are zero-one dummies based on the second (2003) wave of the World Bank's

Regulation and Supervision Survey, and employing essentially the same definitions as proposed by Barth, Caprio and Levine (2001). Private Monitoring Index is the composite private monitoring index discussed in the text. "No deposit insurance" is coded " 0 " if there is an explicit insurance system and that depositors were wholly compensated (to the extent of legal protection) the last time a bank failed; coded "1" otherwise. "Listed \% of pvt banks" is an approximation to the share of the privatelyowned part of the banking system consisting of banks with a stock market listing. It is a composite indicator based on data from three sources: it divides the aggregate assets of listed banks and bank holding companies (source Bankscope) by the percentage of total banking assets (source IFS), and expresses the result as a percentage of the share of non-government and non-stateowned banks in total banking assets from the Regulation Survey. "Number banks rated" is the number among the largest ten banks which is rated by an international rating agency. "Bank accounts" ranges from 0 to 3 depending on whether interest accrued but unpaid is excluded from bank earnings, whether consolidation of group accounts is required, and whether bank directors are legally liable for misleading information. "Auditing" means external audit by a certified auditor is compulsory. Private Banks is the percentage share of banking assets in banks that are not owned by government or by foreign banking groups. GNP per cap is Gross National Product per capita in Purchasing Power Parity (PPP) terms, hundreds of US dollars; population size is in millions; both 2001, source: World Development Indicators. Two cross product terms with the Private Monitoring Index (PvtMon) are also employed.

$* * *, * *$, and $*$ indicate significance at the $1 \%, 5 \%$, and $10 \%$ levels, respectively. 


\section{Improving Market Discipline}

Regardless of how well market discipline works in developing countries, available evidence suggests that an approach based on official supervision has no significant impact on financial sector development, on the likelihood that the financial system would not be affected by crises, or on the access to credit by firms (Barth, Caprio, and Levine, 2003; and Beck, Demirguc-Kunt and Levine, 2003). Indeed, these studies have suggested that except in environments with well-developed political checks and balances and a highly independent media, improving supervisory powers actually had a negative impact on these variables. Only in extremely advanced institutional settings, with highly developed checks and balances and media independence were broader supervisory powers linked with more positive outcomes.

Many have posited that supervision can only work if the supervisor is highly independent. Empirical evidence on the importance of de jure independence within the government (captured by the ability of administration to remove the supervisor unilaterally) and of independence from the industry being regulated (measured by the extent to which supervisors were protected, at least on paper, from bearing the expense of civil lawsuits and from criminal prosecution for doing their job) both are quite mixed. We suspect that it is not the case that these factors do not matter but rather that it is difficult to capture true independence especially in the former sense from what is written on paper. Even countries in which the de jure independence of the bank supervisor is high, it is plausible that the de facto independence is low where a relatively small number of economic groups or families control a large share of the economy. In these cases, the press also might be captured or even directly controlled by the same narrow group of interests. $^{20}$ To be sure, in such environments, markets may not function as well as they might in economies with more arms-length relationships, but they still appear to be capable of having some impact in monitoring banks. Still, efforts should continue both to better understand the institutional prerequisites for effective bank supervision and to advance the cause of institutional development in these areas. However, given that evidence indicates that market discipline can be effective, then it also makes sense for authorities to focus on how to make it work even better.

Instead, much regulatory attention appears to the influenced by the debate regulatory choices in developed countries, where the emphasis is very much been put on bank capital and on requiring supervisors to take prompt corrective actions in the event of banking distress. Table 5 compares indicators of bank regulation and supervision from the first World Bank survey, with most observations from 1998 or 1999, and the second survey, which was taken in early 2003. Focusing on the original 107 countries responding in the first survey, this table shows the responses grouped by countries at different income levels.

\footnotetext{
20 In fact, one of the authors of this paper visited a country in which a family controlling one of the most important domestically-owned banks and a number of holding companies also had a family member as head of bank supervision. This by the way was in a situation in which the limit on family control of a bank was only $5 \%$ of total equity.
} 
The changes that stand out the most are for the low-income countries, where there has been an significant increase in the stringency of capital regulations and the overall index of capital regulation, a slight decline in official supervisory powers, but a substantial jump in prompt corrective action powers. ${ }^{21}$ Interestingly, low-income country supervisors' discretion to forbear actually increased somewhat - in other words, they have the ability to take prompt corrective action powers, but are not as constrained as they were previously. The one supervisory variable that was found by BCL to have some positive impact on the development of the financial sector and on limiting the occurrence of banking crises, namely requirements that banks diversify their risks, actually decreased in all the countries, including in the low-income countries, where small economic size and insufficient diversification could be a critical issue. Thus it would appear all the more important for authorities to try to strengthen market discipline. Unfortunately, according to the survey, the private monitoring index has decreased somewhat. Part of this decline reflects some spreading of deposit insurance (the absence of which raises this index).

Table 6. Trends in Bank Regulation and Supervision Surveys carried out in 1998-99 (Survey I) and 2003 (Survey II)

\begin{tabular}{llcccc}
\hline \multirow{2}{*}{ Means } & & $\begin{array}{c}\text { High } \\
\text { Income }\end{array}$ & $\begin{array}{c}\text { Upper } \\
\text { Middle }\end{array}$ & $\begin{array}{c}\text { Lower } \\
\text { Middle }\end{array}$ & $\begin{array}{c}\text { Low } \\
\text { Income }\end{array}$ \\
\hline \multirow{2}{*}{ Overall Capital Stringency } & Survey I & $\mathbf{3 . 9 2}$ & 3.29 & $\mathbf{3 . 1 2}$ & 3.11 \\
& Survey II & 3.79 & $\mathbf{3 . 4 5}$ & 3.09 & $\mathbf{4 . 4 0}$ \\
\hline \multirow{2}{*}{ Capital Regulation Index } & Survey I & $\mathbf{5 . 6 1}$ & 5.05 & 4.42 & 4.47 \\
& Survey II & 5.45 & $\mathbf{5 . 2 3}$ & $\mathbf{4 . 7 0}$ & $\mathbf{5 . 6 0}$ \\
\hline \multirow{3}{*}{ Official Supervisory Power } & Survey I & $\mathbf{1 0 . 7 9}$ & $\mathbf{1 1 . 3 3}$ & $\mathbf{1 1 . 1 9}$ & $\mathbf{1 1 . 3 7}$ \\
& Survey II & 10.39 & 10.36 & 10.48 & 10.90 \\
\hline \multirow{2}{*}{ Prompt Corrective Action } & Survey I & 1.49 & 2.71 & 1.85 & 2.47 \\
& Survey II & $\mathbf{1 . 6 3}$ & $\mathbf{3 . 0 0}$ & $\mathbf{2 . 3 9}$ & $\mathbf{4 . 1 0}$ \\
\hline Supervisory Forbearance & Survey I & $\mathbf{1 . 8 7}$ & 1.29 & $\mathbf{1 . 3 8}$ & $\mathbf{1 . 7 2}$ \\
Discretion & Survey II & 1.75 & $\mathbf{1 . 5 5}$ & 1.17 & 1.40 \\
\hline \multirow{2}{*}{ Liquidity / Diversification Index } & Survey I & $\mathbf{1 . 9 2}$ & $\mathbf{2 . 1 0}$ & $\mathbf{2 . 0 0}$ & $\mathbf{1 . 6 8}$ \\
\cline { 2 - 6 } & Survey II & 1.55 & 1.55 & 1.13 & 1.20 \\
\hline \multirow{2}{*}{ Private Monitoring Index } & Survey I & $\mathbf{7 . 0 8}$ & $\mathbf{7 . 1 0}$ & $\mathbf{6 . 7 3}$ & $\mathbf{5 . 4 7}$ \\
\hline & Survey II & 6.87 & 6.36 & 6.04 & 5.40 \\
\hline
\end{tabular}

Note: In each case, the higher value as between the two surveys is shown in bold. Countries are classified by income level into High, Upper-middle, Lower-middle and Low income using standard World Development Indicators classifications, 2003.

Source: World Bank Regulation and Supervision Survey

\footnotetext{
${ }^{21}$ Official supervisory powers, as disaggregated by Barth, Caprio, and Levine (2001) cover a broad array of powers, some related to the ability to implement prompt corrective action, others at supervisors' ability to force restructuring and reorganization, or to declare insolvency.
} 
What does it take to make for better market discipline? Consider the four sources of market discipline for banking, noted above: depositors, debt holders, outside equity holders, and information specialists. First, all of them require accurate and timely information to do the best possible job. This means that regulations or listing requirements that necessitate prompt and thorough disclosure of key information relevant to determining bank performance clearly are to be encouraged. What types of information most need to be disclosed, beyond the standard balance sheet and income statement data?

Certainly there is a case to be made that information on the state of a bank's loan portfolio, and more broadly the credit risk that it has, would be useful for creditors, shareholders, and competitors. Some voluntary disclosure is valuable to banks, both lowering their cost of funds and the volatility of their equity price (Baumann and Nier, 2003). However, there is a clear externality - individual banks are not rewarded for reducing the volatility or funding costs of their competitors - and therefore will not disclose sufficiently credit risk information. If banks were forced to mark their portfolios to market, reporting requirements would be far easier. The absence of this practice - due no doubt to its difficulty, and the related nontradeability of much bank debt -- means that a significant amount of information pertaining to credit, market, and operational risks of banks is required in order to make a reasonable estimate of their health.

One piece of critical information that does not get adequately disclosed (and which would greatly benefit both share and debt holders of banks) is the compensation structure of bank management. The market really needs to be able to understand the extent to which it is risktaking or prudence that is being rewarded. Banks and other firms surely will resist such disclosure, but compensation structures should be factoring into either minimum capital requirements and/or the price charged by the market for outside funding.

As became clear in recent scandals in the United States, it is important that information specialists, such as rating agencies and auditors, are acting at arm's length from the clients whose information they are certifying. In addition to occasionally discussed proposals to make these actors liable for their opinions, it is possible for a regulatory body at the very least to publish their track records, such as the number of times that a client receiving a favorable view from the agency in question has subsequently, within some short time period, developed problems. There is a difference of opinion as to whether these agencies should have their activities restricted, e.g. preventing accounting firms who audit a company from picking up other consulting business. But what needs to be disclosed is not only where such relationships exist, but also the compensation structure for the officers of the accounting firm. This needs to include not just the level of compensation, but importantly the formula that determines it. Such a disclosure would have flagged serious incentive problems at Arthur Andersen, the auditor of Enron and other failed companies. It would also likely help augment market discipline from information specialists. 
In addition to information that is required by government regulation, available information also depends on the incentives that banks have to release it, and that others have to report it. For example, in the United States prior to the adoption of deposit insurance, there used to be daily and weekly newspapers that followed the performance of bank notes issued by various commercial banks. There was a market for this reporting because the holders of these notes understood that they were subject to losses.

Second, beyond the information that is available, it follows that markets need the incentive to act. As suggested by studies referred to earlier, depositors' incentives to monitor the health of the banks in which they put their money is reduced to the extent that they are credibly insured, and the greater is this insurance. Perhaps the best illustration of this was the study by Demirguc-Kunt and Huizinga (2004), which found that in countries with explicit deposit insurance, banks that were expanding their lending portfolio rapidly did not pay much of the increased cost for their funds, whereas in countries without explicit deposit insurance, the cost of funds rose smartly as banks attempted to expand. Moreover, most developing countries that offer deposit insurance appear to underprice it substantially (Laeven, 2002), and a number have exceptionally generous deposit insurance ceilings, with some even offering blanket deposit insurance for all deposits. Scaling back deposit insurance coverage, thereby increasing the share of deposits that are not insured, should increase monitoring by those uninsured, while still protecting small depositors, who in most cases possess little comparative advantage in monitoring banks. Thus deposit insurance ceilings of about one to two times per capita GDP - about the norm in higher income countries -- likely have little cost in reducing the effective degree of market monitoring that is conducted.

Moreover, the generous availability of deposit insurance may convince debtholders that the authorities are reluctant to allow anyone to suffer losses, and without the fear of losses is not likely that debtholders will invest in monitoring banks. Thus it is important, in order to improve market monitoring, that authorities send strong and consistent signals that uninsured debtholders will not have their losses covered by the government.

In addition to increasing the likelihood that debtholders might face losses is the need to increase in the preponderance of bank liabilities in the form of uninsured debt. Even if all other features of a deposit insurance scheme appear to be well designed, an excessively low price for that insurance will encourage an expansion of insured deposit liabilities relative to total liabilities. If banks bear the costs of deposit insurance premia, then a high price will make them reluctant to raise insured deposits and more eager to raise uninsured debt. On the other hand if banks passed on the cost of deposit insurance premia to the ultimate deposit holders, then potential depositors will themselves prefer to hold non-deposit debt. Subordinated debt proposals (see Kaufman, 2003; Calomiris, 1999, Evanoff and Wall, 2001) have in common requirements that banks issue junior debt in relatively large lumps, in order to avoid the free rider problem that is thought to limit monitoring by small depositors. The complaint that banks find subordinated debt costly to issue may be biased by the subsidy associated with generous deposit insurance 
schemes; in other words subordinated debt certainly is costly relative to insured deposits with a hefty government subsidy built into the insurance premium.

An additional benefit of taking steps to increase market monitoring is that it is complementary with effective bank supervision. For example, recall the environment suggested above, in which a few families or powerful interest groups control a large segment of the economy. These interest groups will find it in their interest to try to influence government supervision. However, to the extent that they are forced to disclose data that may indicate certain problems in their banks, 'countervailing powers,' including pressure on political authorities to insure that appropriate actions are taken may arise. Such pressure is more likely to the extent that there is at least some part of the media or the electorate that is well informed about and understands financial sector issues. Requirements that supervisors take actions in certain situations may be helpful as well, but if the vested interests are sufficiently powerful and there is no offsetting interest group pushing in the other direction, then attempts to ensure prompt corrective action may fail. Indeed, such pressures may explain why Barth, Caprio, and Levine (2003) found no evidence that greater supervisory powers had beneficial effects on the financial sector.

As has been suggested before, one of the benefits of mandatory subordinated debt issuance by banks is that the price of this debt will tell supervisors which banks need more of their attention. In the case of Argentina, it was said that the thinness of the debt market prevented it from revealing significant information. Still, the inability of some banks to comply with subordinated debt requirements predicted quite well which banks needed supervisory intervention, and certainly was associated clearly with the level of nonperforming loans (Calomiris-Powell, 2001). As noted in the case of the United States, it seems that the primary issuance market is the most significant, and thus the lack of a well-developed secondary market should serve as no obstacle to enhancing market discipline though a subordinated debt requirement.

\section{Conclusions}

Market discipline on banks can help alert regulators to risky or self-serving behavior by bank insiders; it can also act directly on insider incentives. But market discipline is unlikely to emerge in the absence of relevant market and information infrastructures, and where explicit or implicit government guarantees stifle the incentive for depositors, debtand outside equity-holders, or information specialists to exercise such discipline.

The widespread belief that market discipline on managers and controlling shareholders of privately-owned banks cannot be effective in less developed financial environments was questioned. For one thing, many of the privately owned banks in the developing world are foreign-owned. As such, the foreign private sector in the home countries - typically more developed - of these banks, will also be exercising discipline. Besides, the quality and relevance of information available to large depositors on the probity and skills of local bank management is arguably higher in less sophisticated settings - and relatively 
higher than that available to official regulators. In general, we find more reason to think that market discipline works certainly better in lower-income countries than pre-existing beliefs generally held. Countries should build on any success in this area by limiting the role of explicit deposit guarantees, reducing state ownership of banks where it is prevalent, and by not putting all their eggs in the supervisory basket. Greater disclosure, for example, of how risk taking is rewarded and how rating agencies earn their fees would support the development of better market monitoring. More broadly, it seems that greater emphasis on the third pillar in the Basel II Accord than on the refinements of the risk-weighting system of the first pillar may be warranted for most developing countries. 


\section{References}

Baer, Herbert and Elijah Brewer. 1986. "Uninsured deposits as a source of market discipline: some new evidence," Economic Perspectives (September) 23-31.

Barajas, Adolfo and Roberto Steiner. 2000. "Depositor behavior and market discipline in Colombia”, IMF Working Paper 00/214

Barth, James R., Gerard Caprio, Jr. and Ross Levine. 2001. "The Regulation and Supervision of Bank Around the World: A New Database," in Robert E. Litan and Richard Herring, Editors, IntegratingEmerging Market Countries into the Global Financial System, Brookings-Wharton Papers on Financial Services, Brookings Institution Press, p.183-240.

Barth, James R., Gerard Caprio, Jr. and Ross Levine. 2003. "Bank Regulation and Supervision: What Works Best?" Journal of Financial Intermediation, forthcoming.

Baumann, Ursel, and Erlend Nier. 2003. "Disclosure in Banking: What Matters Most," mimeo, paper presented at the NY Fed conference on Market Discipline.

Beck, Thorsten, Asli Demirgüç-Kunt and Ross Levine, 2003, "Law, Endowments and Finance" Journal of Financial Economics, forthcoming.

Berger, A., S. Davies and M. Flannery. 2000. "Comparing Market and Supervisory Assessments of Bank Performance: Who Knows What When?" Journal of Money, Credit and Banking 32.

Bliss, Robert R. and Mark J. Flannery. 2001. "Market Discipline in the Governance of U.S. Bank Holding Companies: Monitoring vs. Influencing”, in Mishkin, F.S. ed. Prudential Supervision: What Works and What Doesn't. (University of Chicago Press).

Board of Governors of the Federal Reserve System. 1999. Using Subordinated Debt as an Instrument of Market Discipline, Staff Study 172.

Bongini, P., L. Laeven and G. Majnoni. 2002. "How Good is the Market at Assessing Bank Fragility? A Horse Race between Different Indicators", Journal of Banking and Finance 26:1011-28.

Calomiris, Charles W. 1999a. The Postmodern Bank Safety Net: Lessons from Developed and Developing Economies, Washington, D.C.: American Enterprise Institute.

Calomiris, Charles. 1999b. "Building an Incentive-Compatible Safety Net," Journal of Banking and Finance 23(1): 1499-519 
Calomiris, Charles W., and Charles Kahn. 1991. "The Role of Demandable Debt in Structuring Optimal Banking Arrangements." American Economic Review 81(3):497513.

Calomiris, Charles and Andrew Powell. 2001. "Can Emerging Market Bank Regulators Establish Credible Discipline? The Case of Argentina, 1992-1999," in Mishkin, F.S. ed. Prudential Supervision: What Works and What Doesn't. (University of Chicago Press).

Collin-Dufresne Pierre, Robert S. Goldstein and J. Spencer Martin. 2001. "The Determinants of Credit Spread Changes", The Journal of Finance, December.

Covitz, Daniel, Diana Hancock, and Myron Kwast. 2003. " Market Discipline in Banking Reconsidered: the Roles of Deposit Insurance Reform and Funding Manager Decisions, mimeo, Federal Reserve Board.

D’Amato, Laura, Elena Grubisic, and Andrew Powell. 1997. "Contagion, Bank Fundamentals or Macroeconomic Shock? An Empirical Analysis of the Argentine 1995 Banking Problems" Banco Central de la Republica Argentina, Working Paper 2.

Davies, Sally, and Patrice Robitaille. 1997. "Market Discipline and Bank Certificates of Deposit: Evidence from Chile," Board of Governors of the Federal Reserve System, mimeo.

Demirguc-Kunt, Asli and Harry Huizinga, 2004. "Market Discipline and Deposit Insurance," Journal of Monetary Economics, forthcoming.

De Nicoló, Gianni, Philip Bartholomew, Jahanara Zaman, and Mary Zephirin. 2003.

"Bank Consolidation, Internationalization and Conglomeration: Trends and Implications for Financial Risk,” IMF Working Paper 03/158.

De Young, Robert, Mark Flannery, William Lang and Sorin Sorescu. 2001. "The Information Content of Bank Exam Ratings and Subordinated Debt Prices", Journal of Money, Credit and Banking, forthcoming.

Diamond, Douglas W. and Philip H. Dybvig. 1983. "Bank Runs, Deposit Insurance, and Liquidity," Journal of Political Economy 91: 401-419.

Evanoff, Douglas, and Larry Wall. 2000. "Subordinated Debt and Bank Capital Reform,” Federal Reserve Bank of Chicago Working Paper WP 2000-07, August.

Evanoff, Douglas D. and Larry D. Wall. 2001. "Sub-debt Yield Spreads as Bank Risk Measures”, Journal of Financial Services Research 19(2/3), December.

Flannery, Mark. 1998. "Using Market Information in Prudential Bank Supervision: A Review of the U.S. Empirical Evidence," Journal of Money, Credit, and Banking 30, 273-305. 
Flannery, Mark. 2001. “The Faces of Market Discipline”, Journal of Financial Services Research 20(1-2):107-119.

Flannery, Mark and Sorin Sorescu. 1996. "Evidence of Bank Market Discipline in Subordinated Debenture Yields: 1983-1991," The Journal of Finance 4, 1347-1377.

Gropp, Reint and Anthony J. Richards. 2001. "Rating Agency Actions and the Pricing of Debt and Equity of European Banks: What Can We Infer about Private Sector Monitoring of Bank Soundness?" Economic Notes 30(3): 373-98

Gropp, Reint and Jukka Vesala. 2001. "Deposit Insurance and Moral Hazard: Does the Counterfactual Matter?”, European Central Bank Working Paper 47.

Gropp Reint, Jukka Vesala and Giuseppe Vulpes. 2002. "Equity and Bond Market Signals as Leading Indicators of Bank Fragility in Europe," European Central Bank Working Paper 150.

Hannan, Timothy H., and Gerald A. Hanweck. 1988. "Bank Insolvency Risk and the Market for Large Certificates of Deposit," Journal of Money, Credit and Banking 20(2): 203-211.

Hellman, Thomas, Kevin Murdock and Joseph Stiglitz. 2000. "Liberalization, Moral Hazard in Banking and Prudential Regulation: Are Capital Requirements Enough?" American Economic Review 90(1):147-65.

Kaufman, George, 2003. "Basel II: The Roar that Moused," mimeo, Loyola University.

Karacadag, Cem and Animesh Shrivastava. 2000. "Mandatory Subordinated Dent in Capital Regulation: Theory and Practice,” IMF Working Paper 00/215.

Kroszner, Randall. 1997. "Free Banking: The Scottish Experience as a Model for Emerging Economies" in Gerard Caprio, Jr. and Dimitri Vittas, eds. Reforming Financial Systems: Historical Implications for Policy (New York: Cambridge University Press).

Laeven, Luc. 2002. "Pricing of Deposit Insurance", World Bank Policy Research Working Paper 2871.

Lamoreaux, Naomi. 1994. Insider Lending: Banks, Personal Connections, and Economic Development in Industrial New England (New York: Cambridge University Press).

La Porta, Rafael, Florencio Lopez-de-Silanes, Andrei Shleifer, and Robert W. Vishny. 1999. "The Quality of Government," Journal of Law, Economics, and Organization, 15(1): 222-279. 
Martinez Peria, Maria Soledad and Sergio Schmukler. 2001. "Do Depositors Punish Banks for "Bad" Behavior?: Market Discipline, Deposit Insurance, and Banking Crises?" Journal of Finance 56(3) 1029-51.

Mondschean, Thomas S., and Timothy P. Opiela. 1999. "Bank Time Deposit Rates and Market Discipline in Poland: The Impact of State Ownership and Deposit Insurance Reform," Journal of Financial Services Research, 15(3): 179-196.

Morgan, Donald P. and Kevin J. Stiroh. 1999. "Bond Market Discipline of Banks: Is the Market Tough Enough?” Federal Reserve Bank of New York Working Paper.

Morgan, Donald P. and Kevin J. Stiroh. 2001. Market Discipline of Banks: the Asset Test, Journal of Financial Services Research, 20, no. 2/3 (2001): 195-208.

Opiela, Timothy P. 2001. "Deposit Market Discipline in Pre-Crisis Thailand:

Implications for Modeling the Thai Crisis and Developing a DIS" Presented at the Federal Reserve Bank of Chicago 2001 Annual Bank Structure Conference.

Park, Sangkyun and Stavros Peristiani. 1998. "Market Discipline by Thrift Depositors," Journal of Money, Credit and Banking 30 (3): 347-364.

Richards, Anthony and David Deddouche. 1999. "Bank Rating Changes and Bank Stock Returns: Puzzling Data from the Emerging Markets,” IMF Working Paper 99/151.

Saunders, Anthony. 2001. "An Analysis of Bank Charter Value and Its Risk Constraining Incentives," Journal of Financial Services Research.

Schumacher, Liliana. 1996. "Bubble or Depositor's Discipline? A Study of the Argentine Banking Panic (December 1994/May 1995),” Ph.D. Dissertation, University of Chicago.

Sironi, Andrea. 2000. "Testing for Market Discipline in the European Banking Industry: Evidence from Subordinated Debt Issues", Federal Reserve Board, Finance and Economics Discussion Series, 40-2000.

Sironi, Andrea. 2001a. "An Analysis of European Banks Subordinated Debt Issues and Its Implications for a Mandatory Subordinated Debt Policy", Journal of Financial Services Research, 20(2/3), December.

Sironi, Andrea. 2001b. "Strengthening Banks' Market Discipline and Leveling the Playing Field: Are the Two Compatible?" Presented at Bank of England Conference.

Wagster, John D. 1996, "Impact of the 1988 Basle Accord on International Banks", Journal of Finance 51, 1321-1346.

World Bank. 2001. Finance for Growth: Policy Choices in a Volatile World. World Bank, Washington D.C. and Oxford University Press, New York. 
Valdes, Salvador and Alexandra Lomakin. 1988. "Percepcion Sobre la Garantia Estatal a los Depositos Durante 1987 en Chile," Cuardernos de Economia 25:75, 229-245.

\section{Box: Subordinated debt of a Lebanese bank - tracking the government or the bank?}

Examining the prices of tradable debt and equity of Lebanon's largest bank BLOM is instructive as to the potential and limitations of secondary bond and equity markets for privately-owned banks in a lower middle-income economy. BLOM is effectively controlled by a group of 5 families, who between them control over 30 percent of the shares. A further 23 percent are traded as depository receipts (GDR). The bank has 13 percent of the Lebanese market and reported US\$7.1 billion in total assets ( $\$ 6$ billion in deposits) at end 2002. Shareholders' fund in the bank are about $\$ 0.6$ billion and its end2002 market value of the equity was about $\$ 1.4$ billion. Thus BLOM is only a modestly sized bank by advanced economy standards. Its 10-year subordinated US-dollar denominated note (coupon 9\%, maturing 2005) is traded in Beirut and Luxembourg. The GDRs are also traded in Beirut and Luxembourg.

We show charts comparing the yield on the subordinated debt to the GDR price and to the yield on a Government of Lebanon eurobond with approximately the same coupon and maturity $(83 / 4 \%, 2005) .{ }^{22}$ The charts are plotted in transaction time; that is to say, the only dates shown are those on which there was a transaction in one or both of the assets; the price shown is the price of that day's transaction or, for a security not traded on that day, the price at the last transaction. The period covered is April 2002 to September 2003. This was a dramatic period in the fortunes of the Lebanon financial markets. In the period before November 2002, a difficult fiscal environment caused capital outflows, a sharp fall foreign exchange reserves of the central bank and the spread on Government of Lebanon eurobonds widening to more than 1100 basis points. The grant of substantial concessionary funding by the French Government and other donors at a conference in Paris on November 23, 2002 resulted in a sharp narrowing of the spread by about 400 basis points, as seen in Figure A.2. The Beirut equity market also recovered and the central bank's foreign exchange reserves have subsequently been amply replenished.

The fortunes of BLOM bank are, of course, not unrelated to the fiscal situation in Lebanon. For one thing, over a third of the bank's assets are held in Lebanese Government obligations. Thus it is not surprising to see (in Figure A.1) the bank's equity appreciating by about 40 percent from November 2002 to July 2003 (international bank equity trends would also be a factor here). The yield on the bank's debt also declines from November 2002 on. Nevertheless, we see from Figure A.2 that the yield on BLOM debt did not closely track the sovereign eurobond during the period of pressure. Even though transactions were few, it seems that BLOM bank debt continued to yield less than 9 percent during the summer of 2002, while sovereign debt yielded almost $131 / 2$ percent. However, after the Paris aid package, the bank bond tracks the eurobond fairly closely,

\footnotetext{
${ }^{22}$ The debt yields are shown both in absolute terms and as spreads over a US Treasury bond of comparable maturity.
} 
with the yield spread ranging from minus 83 to plus 71 basis points and averaging just 2 basis points.

The charts suggest a few considerations about the use of bank debt and equity prices for inferring market discipline. For example:

- The debt and equity of even relatively small banks are increasingly traded in international markets. It is potentially an international market that exercises discipline through these capital market instruments.

- The markets are rather inactive (if the trades reported in Bloombergs, on which the figures are based, are comprehensive), and as such do not necessarily give very up-to-date information about market expectations. Bloomberg's report no trades in either the sovereign eurobond nor the bank's sub debt from July 2002 to the end of October 2002.

- Given the lack of depth in the markets, care should be taken in inferring movements in bank-specific default risk from asset price movements; idiosyncratic liquidity shocks are a more likely cause of asset price movements for a well-capitalized bank such as BLOM. (Examination of the data on two other bank bonds - available only in 2003 and not shown here - confirms this point: the yields have a strong comovement, yet also experience swings of up to 100 basis points, strongly suggest the result of liquidity trading.)

- There may be no robust reference price against which to compare the asset prices in order to infer movements in default risk. When the spread of a bank's debt over the sovereign is a negative 350 basis points, movements in the yield are as likely to reflect a changing perceptions of how sovereign risk should be factored into the prices of a bank's assets.

- It might be possible for insiders to manipulate market prices of inactively traded debt by effecting small artificial transactions from time to time. Perhaps the 400 basis point reverse spread on the bank bond in mid-2002 does not reflect market sentiment. 


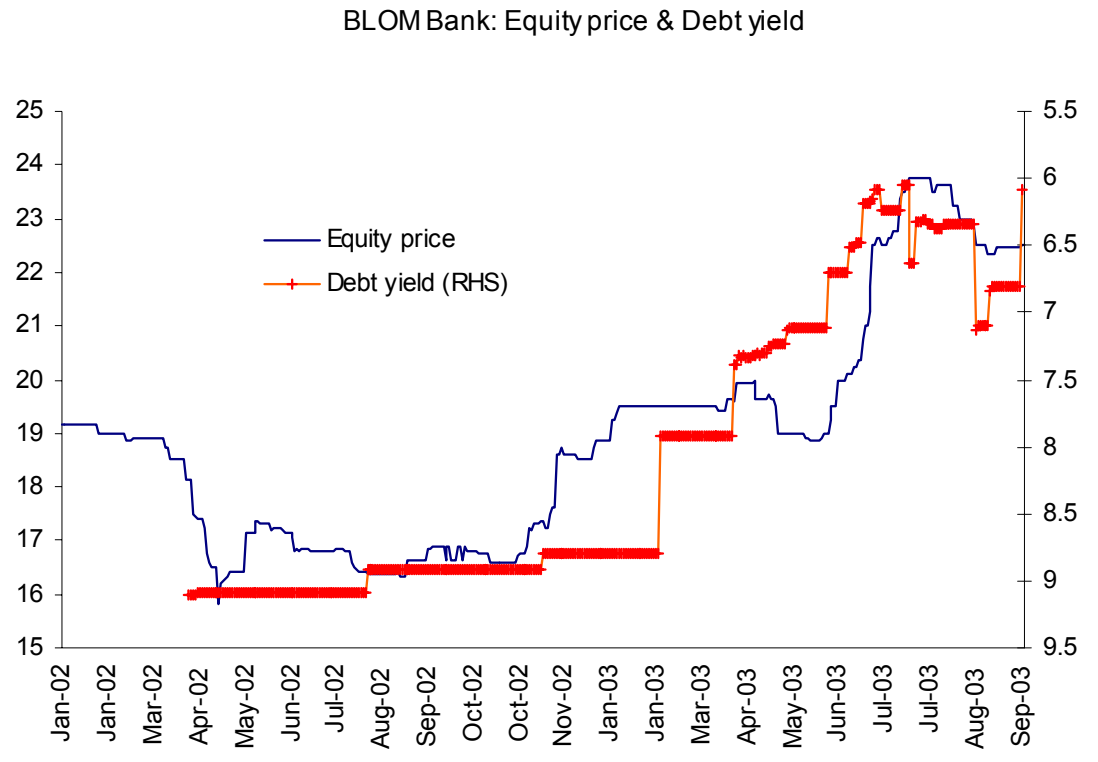

Figure A.1 Yield on BLOM Bank Global Depository Receipt \& BLOM 9\% Subordinated Debt, 2005

Transactions dates Jan 2002-September 2003 


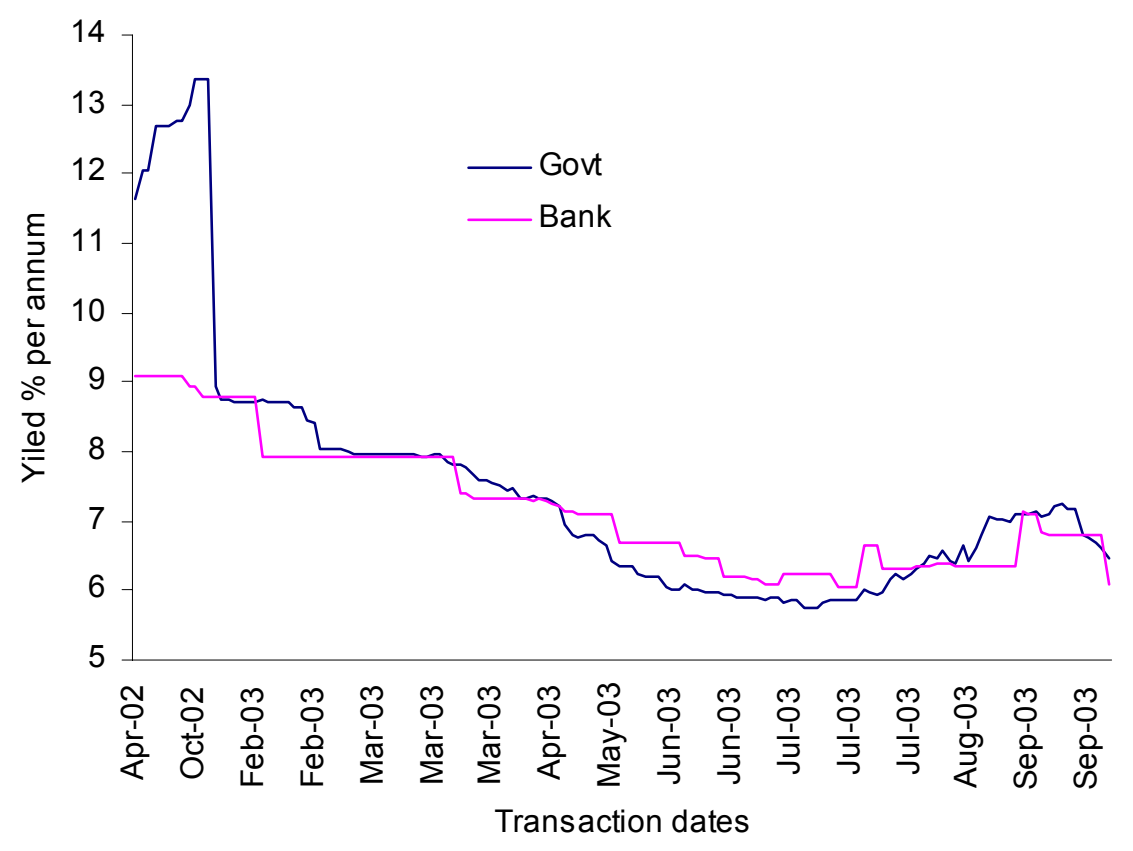

Lebanon: Govt and Bank Bonds

Spreads over US Treasuries

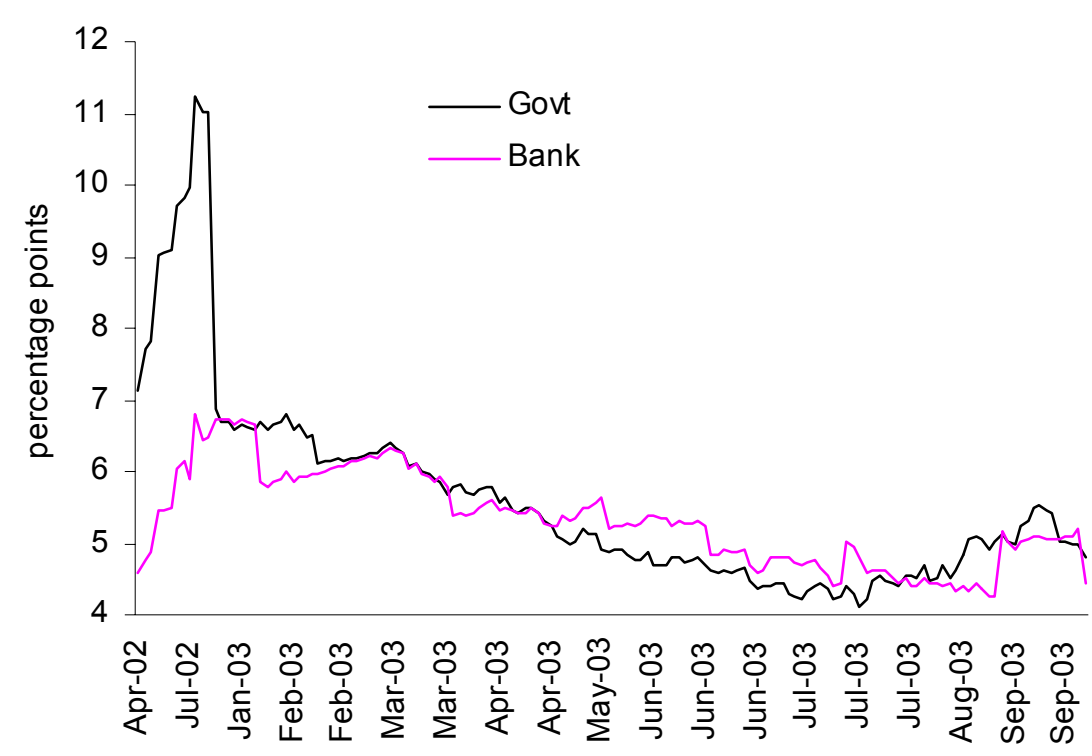

Figure A.2: Yields on Lebanese Government 8.75\% Eurobond, 2005 and BLOM Bank 9\% Subordinated Debt, 2005

Transactions dates April 2002-September 2003. 